\title{
Review
}

\section{Molecular Genetics and Biophysics of Prions}

\section{Stanley B. Prusiner}

Departments of Neurology and of Biochemistry and Biophysics

University of California, San Francisco, California

Address all correspondence to Dr. Prusiner at : Department of Neurology, HSE-781, University of California, San Francisco, CA 94143-0518;

telephone(415)476-4482; fax(415)476-8386

\section{Introduction}

Prions cause a group of human and animal neurodegenerative diseases which are now classified together because their etiology and pathogenesis involve modification of the prion protein

(PrP) ${ }^{1}$. Prion diseases are manifest as infectious, genetic and sporadic disorders (Table 1). These diseases can be transmitted among mammals by the infectious particle designated "prion" ${ }^{2}$. Despite intensive searches over the past three decades, no nucleic acid has been found within prions ${ }^{3-6)}$; yet, a modified isoform of the host-encoded PrP designated $\mathrm{PrP}^{\mathrm{Sc}}$ is essential for infectivity ${ }^{1,7-10}$. In fact, considerable experimental data argue that prions are composed exclusively of $\mathrm{PrP}^{\mathrm{sc}}$. Earlier terms used to describe the prion diseases include: transmissible encephalopathies, spongiform encephalopathies and slow virus diseases ${ }^{11-13)}$.

The quartet of human $(\mathrm{Hu})$ prion diseases are frequently referred to as kuru, Creutzfeldt-Jakob disease (CJD), Gerstmann-Sträussler-Scheinker

(GSS) disease and fatal familial insomnia (FFI). Kuru was the first of the human prion diseases to be transmitted to experimental animals and it has often been suggested that kuru spread among the Fore people of Papua New Guinea by ritualistic cannibalism $^{12,14}$. The experimental and presumed human to human transmission of kuru led to the belief that prion diseases are infectious disorders

本論文は第42回ウイルス学会総会 公開講演会「プリオン研 究の進展」における講演内容をまとめたものである。 caused by unusual viruses similar to those causing scrapie in sheep and goats. Yet, the occurrence of CJD in famillies, first reported almost 70 years $\mathrm{ago}^{15,16)}$, was perplexing to say the least. The significance of familial CJD remained unappreciated until mutations in the protein coding region of the $\mathrm{PrP}$ gene on the short arm of chromosome 20 were discovered $^{17-19)}$. The earlier finding that brain extracts from patients who had died of familial prion diseases inoculated into experimental animals often transmit disease, posed a conundrum that was resolved with the genetic linkage of these diseases to mutations of the PrP gene ${ }^{20-22)}$.

The most common form of prion disease is sporadic CJD. Many attempts to show that the sporadic prion diseases are caused by infection have been unsuccessfu1 ${ }^{23-26)}$. The discovery that inherited prion diseases are caused by germline mutation of the $\operatorname{PrP}$ gene raised the possibility that sporadic forms of these diseases might result from a somatic mutation $^{21}$. The discovery that $\operatorname{PrP}^{\mathrm{sc}}$ is formed from the cellular isoform of the prion protein, $\mathrm{PrP}^{\mathrm{c}}$, by a post-translational process ${ }^{27)}$ and that overexpression of wild-type (wt) PrP transgenes produces spongiform degeneration and infectivity de novo ${ }^{28)}$ has raised the possibility that sporadic prion diseases result from the spontaneous conversion of $\operatorname{PrP}^{\mathrm{c}}$ into $\operatorname{Pr} \mathrm{P}^{\mathrm{sc}}$.

CJD has a worldwide incidence of -1 case per $10^{6}$ population ${ }^{29}$. Less than $1 \%$ of CJD cases are infectious and all of those appear to be iatrogenic. Between 10 and $15 \%$ of prion disease cases are inherited while the remaining cases are sporadic. Kuru was once the most common cause of death 
among New Guinea women in the Fore region of the Highlands ${ }^{14,30,31)}$ but has virtually disappeared with the cessation of ritualistic cannibalism ${ }^{32}$. Patients with CJD frequently present with dementia but $-10 \%$ of patients exhibit cerebellar dysfunction initially. Patients with either kuru or GSS usually present with ataxia while those with FFI manifest insomnia and autonomic dysfunction ${ }^{33-35)}$.

$\operatorname{PrP}^{C J D}$ has been found in the brains of most patients who died of prion disease. The term $\mathrm{PrP}^{\mathrm{CJD}}$ is preferred by some investigators when referring to the abnormal isoform of HuPrP in human brain. Here $\operatorname{PrP}^{\mathrm{sc}}$ is used interchangeably with $\operatorname{PrP}^{\mathrm{CJD}}$. $\mathrm{PrP}^{\mathrm{sc}}$ is always used after human CJD prions have been passaged into an experimental animal since the nascent $\mathrm{PrP}^{\mathrm{sc}}$ molecules are produced from host $\operatorname{PrP}^{\mathrm{C}}$ and the $\operatorname{PrP}^{\mathrm{CJD}}$ in the inoculum only serves to initiate the process. In the brains of some patients with inherited prion diseases as well as transgenic

( $\mathrm{Tg}$ ) mice expressing mouse (Mo) PrP with the human GSS point mutation (Pro $\rightarrow$ Leu), detection of $\mathrm{PrP}^{\mathrm{sc}}$ has been problematic despite clinical and neuropathologic hallmarks of neurodegeneration 36.37) Presumably, neurodegeneration is due, at least in part, to the abnormal metabolism of mutant $\mathrm{PrP}^{36)}$ Of note, horizontal transmission of neurodegeneration from the brains of patients with inherited prion diseases to inoculated rodents has been less frequent than with sporadic cases ${ }^{22)}$ Whether this distinction between transmissible and non-transmissible inherited prion diseases will parsist is unclear. Tg mice expressing a chimeric $\mathrm{Hu} /$ Mo PrP gene have been found to be highly susceptible to $\mathrm{Hu}$ prions from sporadic and iatrogenic CJD cases $^{38)}$. These Tg (MHu2M) mice should make the use of apes and monkeys for the study of human prion diseases unnecessary and allow for tailoring the $\mathrm{PrP}^{\mathrm{C}}$ translated from the transgene to match the sequence of the $\operatorname{PrP}^{\mathrm{CJD}}$ in the inoculum. Other $\mathrm{Tg}$ mouse studies have demonstrated that $\mathrm{PrP}^{\mathrm{sc}}$ in the inoculum interacts preferentially with homotypic $\mathrm{PrP}^{\mathrm{C}}$ during the propagation of prions ${ }^{39.40)} \mathrm{PrP}^{\mathrm{C}}$ is the cellular isoform of the prion protein which has been identitied in all mammals and birds examined to date; $\mathrm{PrP}^{\mathrm{c}}$ is anchored to the external surface of cells by a glycolipid moiety and its function is unknown ${ }^{41)}$

Scrapie is the most common natural prion disease of animals. An investigation into the etiology of scrapie followed the vaccination of sheep for looping ill virus with formalin-treated extracts of ovine lymphoid tissue unknowingly contaminated with scrapie prions ${ }^{42)}$. Two years later, more than 1500 sheep developed scrapie from this vaccine. While the transmissibility of experimental scrapie became well established, the spread of natural scrapie within and among flocks of sheep remained puzzling. Parry argued that host genes were responsible for the development of scrapie in sheep. He was convinced that natural scrapie is a genetic disease which could be eradicated by proper breeding proto$\operatorname{cols}^{43,44)}$. He considered its transmission by inoculation of importance primarily for laboratory studies and communicable infection of little consequence in nature. Other investigators viewed natural scrapie as an infectious disease and argued that host genetics only modulates susceptibility to an endemic infectious agent ${ }^{45}$.

The offal of scrapied sheep in Great Britain is thought to be responsible for the current epidemic of bovine spongiform encephalopathy (BSE) or mad cow disease ${ }^{46}$. Prions in the offal from scrapieinfected sheep appear to have survived rendering which produced meat and bone meal (MBM). After BSE was recognized, MBM produced from domestic animals was banned from further use. Since 1986 when BSE was first recognized, >130,000 cattle have died of BSE. Whether humans will develop CJD after consuming beaf from cattle with BSE prions is of considerable concern.

The fundamental event in prion diseases seems to be a conformational change in PrP. All attempts to identify a post-translational chemical modification that distinguishes $\mathrm{PrP}^{\mathrm{Sc}}$ from $\mathrm{PrP}^{\mathrm{c}}$ have been unsuccessful to date ${ }^{47)}$. $\operatorname{PrP}^{\mathrm{c}}$ contains $\sim 45 \% \alpha \sim$ helix and is virtually devoid of $\beta$-sheet ${ }^{48}$. Conversion to $\mathrm{PrP}^{\mathrm{sc}}$ creates a protein which contains $30 \% \alpha$ helix and $45 \% \beta$-sheet. The mechanism by which $\mathrm{PrP}^{\mathrm{c}}$ is converted into $\mathrm{PrP}^{\mathrm{sc}}$ remains unknown but $\mathrm{PrP}^{\mathrm{c}}$ appears to bind to $\mathrm{PrP}^{\mathrm{sc}}$ to form an intermedi- 


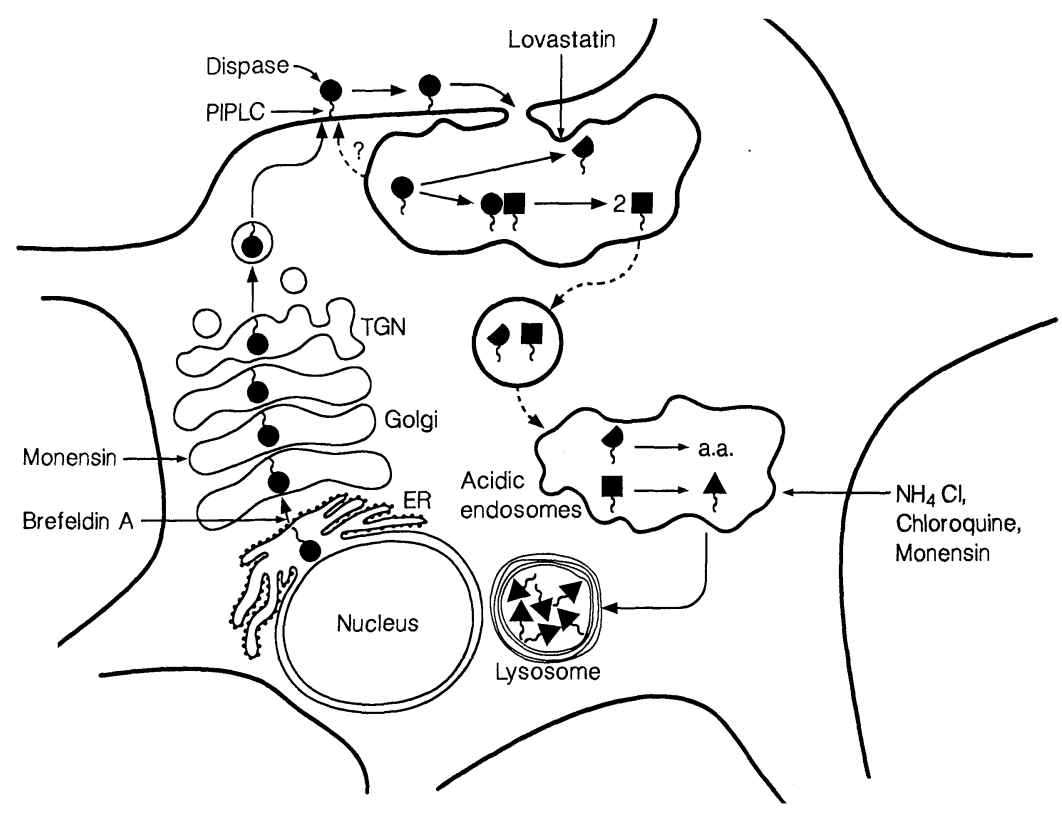

FIGURE 1

Pathways of prion protein synthesis and degradation in cultured cells. $\operatorname{PrP}^{\mathrm{sc}}$ is denoted by squares; circles designate $\mathrm{PrP}^{\mathrm{c}}$. Prior to becoming protease resistant, the $\mathrm{PrP}^{\mathrm{sc}}$ precursor transits through the plasma membrane and is sensitive to dispase or PIPLC added to the medium. PrPsc formation probably occurs in a compartment accessible from the plasma membrane, such as caveolae or early endosomes, both of which are non-acidic compartments. The synthesis of nascent $\operatorname{PrP}^{\mathrm{sc}}$ seems to require the interaction of $\mathrm{PrP}^{\mathrm{c}}$ with existing $\mathrm{PrP}^{\mathrm{sc}}$. In cultured cells, but not brain, the $\mathrm{N}$-terminus of $\mathrm{PrP}^{\mathrm{sc}}$ is trimmed to form $\operatorname{PrP} 27.30$; $\mathrm{PrP}^{\mathrm{sc}}$ then accumulates primarily in secondary lysosomes. The inhibition of $\mathrm{PrP}^{\mathrm{Pc}}$ synthesis by brefeldin A demonstrates that the endoplasmic reticulum (ER)-Golgi is not competent for its synthesis and that transport of PrP down the secretory pathway is required for the formation of $\mathrm{PrP}^{\mathrm{sc}}$.

ate complex during the formation of nascent $\mathrm{PrP}^{\mathrm{sc}}$.

Prions differ from all other known infectious pathogens in several respects. First, prions do not contain a nucleic acid genome which codes for their progeny. Viruses, viroids, bacteria, fungi and parasites all have nucleic acid genomes that code for their progeny. Second, the only known component of the prion is a modified protein that is encoded by a cellular gene. Third, the major, and possibly only, component of the prion is $\mathrm{PrP}^{\mathrm{sc}}$ which is a pathogenic conformer of $\mathrm{PrP}^{\mathrm{c}}$.

As our knowledge of the prion diseases increases and more is learned about the molecular and genetic characteristics of prion proteins, these disorders will undoubtedly undergo modification with respect to their classification. Indeed, the discovery of the
$\operatorname{PrP}$ and the identification of pathogenic PrP gene mutations have already forced us to view these illnesses from perspectives not previously imagined.

\section{Formation of $\mathrm{PrP}^{\mathrm{sc}}$}

Whether $\operatorname{PrP}^{\mathrm{c}}$ is the substrate for $\operatorname{PrP}^{\mathrm{Sc}}$ formation or a restricted subset of $\operatorname{PrP}$ molecules are precursors for $\mathrm{PrP}^{\mathrm{sc}}$, remains to be established. Several experimental results argue that $\mathrm{PrP}$ molecules destined to become $\mathrm{PrP}^{\mathrm{sc}}$ exit to the cell surface, as does $\operatorname{PrP}^{(41)}$ prior to its conversion into $\operatorname{PrP}^{\mathrm{sc}}{ }^{49-51)}$.

Like other GPI-anchored proteins, $\operatorname{PrP}^{\mathrm{c}}$ appears to re-enter the cell through a subcellular compartment bounded by cholesterol-rich, detergentinsoluble membranes (A. Taraboulos, M. Scott, A. 
Semenov, D. Avrahami, L. Laszlo, S. B. Prusiner, in preparation) which might be caveolae or early endosomes (Figure 1) ${ }^{52,53)}$. Within this non-acidic compartment, GPI-anchored $\operatorname{PrP}^{\mathrm{C}}$ seems to be either converted into $\mathrm{PrP}^{\mathrm{sc}}$ or partially degraded (A. Taraboulos, M. Scott, A. Semenov, D. Avrahami, L. Laszio, S. B. Prusiner, in preparation). The partially degraded fragment of $\mathrm{PrP}^{\mathrm{C}}$ appears to be the same as the protein previously designated $\operatorname{PrP}^{\mathrm{C}}-11$ in partially purified fractions prepared from Syrian hamster brain ${ }^{54,55)}$. After denaturation $\mathrm{PrP}^{\mathrm{sc}}$, like $\mathrm{PrP}^{\mathrm{c}}$, can be released from the cell membranes by digestion with phospatidylinositol-specific phospholipase $\mathrm{C}$, suggesting that $\mathrm{PrP}^{\mathrm{sc}}$ is tethered only by the GPI anchor ${ }^{56)}$. In scrapie-infected cultured cells, $\mathrm{PrP}^{\mathrm{sc}}$ is trimmed at the N-terminus to form PrP27-30 in an acidic compartment ${ }^{51,57)}$. Whether this acidic compartment is endosomal or lysosomal where $\operatorname{PrP} 27-30$ accumulates ${ }^{58)}$, remains to be dletermined. In contrast to cultured cells, the Nterminal trimming of $\mathrm{PrP}^{\mathrm{sc}}$ is minimal in brain, where little PrP 27-30 is found ${ }^{59)}$. Deleting the GPI addition signal resulted in greatly diminished synthesis of $\operatorname{PrP}^{\mathrm{sc}}{ }^{60}$. In contrast to $\operatorname{PrP}^{\mathrm{c}}, \operatorname{PrP}^{\mathrm{sc}}$ accumulates primarily within cells, where it is deposited in cytoplasmic vesicles, many of which appear to be secondary lysosomes ${ }^{50,51,57,61,62)}$.

Although most of the difference in the mass of PrP 27-30 predicted from the amino acid sequence and observed after post-translational modification is due to complex-type oligosaccharides ${ }^{54)}$ these sugar chains are not required for $\mathrm{PrP}^{\mathrm{Pc}}$ synthesis in scrapie-infected cultured cells, based on experiments with the Asn-linked glycosylation inhibitor tunicamycin and site-directed mutagenesis studies ${ }^{63)}$.

Search for a Chemical Modification. The discovery that the entire ORF of the PrP gene is contained within a single exon, first in Syrian hamsters and later in humans and other animals, argued that $\mathrm{PrP}^{\mathrm{sc}}$ is not generated by alternative splicing ${ }^{18,64-68)}$. This prompted us to search for a posttranslational chemical modification to explain the differences in the properties of these two PrP isofor-

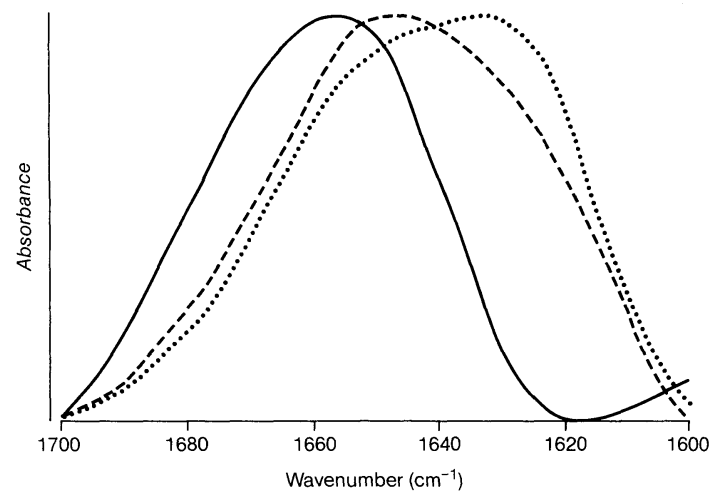

FIGURE 2

Fourier transform infrared spectroscopy of prion proteins. The amide I'band $\left(1700-1600 \mathrm{~cm}^{-1}\right)$ of transmission FTIR spectra of $\operatorname{PrP}^{\mathrm{c}}$ (solid line), $\mathrm{PrP}^{\mathrm{sc}}$ (dashed line) and $\operatorname{PrP}$ 27-30 (dotted line). These proteins were suspended in a buffer in $\mathrm{D}_{2} \mathrm{O}$ containing $0.15 \mathrm{M} \mathrm{NaCl}$ / $10 \mathrm{mM}$ sodium phosphate, pD 7.5 (uncorrected) $/ 0.12 \%$ $\mathrm{ZW}$. The spectra are scaled independently to be full scale on the ordinate axis (absorbance). Reproduced from ${ }^{48)}$

ms ${ }^{47)}$. $\mathrm{PrP}^{\mathrm{sc}}$ was analyzed by mass spectrometry and gas phase sequencing in order to identify any amino acid substitutions or post-translational chemical modifications. The amino acid sequence was the same as that deduced from the translated ORF of the PrP gene, and no candidate post-translational chemical modifications that might differentiate $\operatorname{PrP}^{\mathrm{c}}$ from $\mathrm{PrP}^{\mathrm{sc}}$ were found ${ }^{47)}$. These findings forced consideration of the possibility that conformation distinguishes the two PrP isoforms.

Secondary Structure Prediction Studies. By comparing the amino acid sequences of 11 mammalian and one avian prion proteins, structural analyses predicted four $\alpha$-helical regions ${ }^{69,70)}$. These prediction studies of $\mathrm{SHaPrP}^{\mathrm{c}}$ and $\mathrm{SHaPrP}^{\mathrm{sc}}$ (residues 23-231) were performed using a neural network algorithm ${ }^{71,72)}$. Class dependent $(\alpha / \alpha, \alpha)$ $\beta, \beta / \beta)$ and naive predictions were performed. The $\alpha / \alpha$ class contains proteins that are composed largely of $\alpha$-helices. Similarly, $\beta / \beta$ class contains proteins that are mostly $\beta$-sheets. Interestingly, the four putative $\alpha$-helical domains of $\operatorname{PrP}^{69)}$ showed 

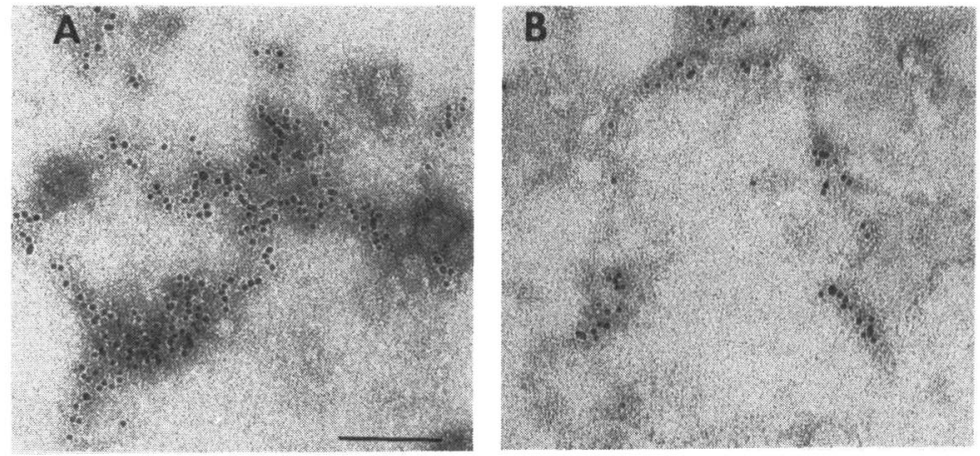

\section{FIGURE 3}

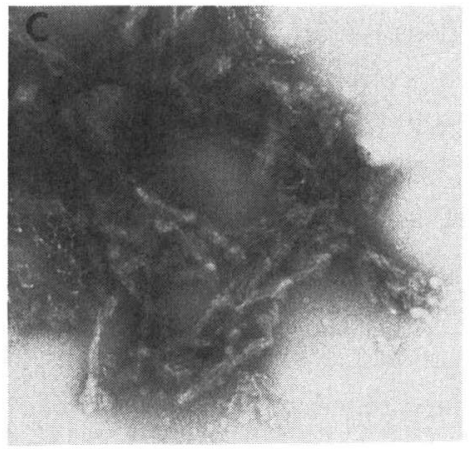

Electron micrographs of negatively stained and immunogold labeled prion proteins: (A) $\operatorname{PrP}^{\mathrm{C}}$ and (B) $\mathrm{PrP}^{\mathrm{sc}}$. (C) Prion rods composed of PrP 27-30 were negatively stained with uranyl acetate. Bar $=$ $100 \mathrm{~nm}$. Reproduced from ${ }^{48)}$.

both strong helix preference in the $\alpha / \alpha$ class prediction and strong $\beta$-sheet preference in the $\beta / \beta$ class prediction. These results are consistent with the hypothesis that these domains undergo conformational changes from $\alpha$-helices to $\beta$-sheets during the formation of $\mathrm{PrP}^{\mathrm{sc}}$. Further support for this hypothesis comes from structural investigations of synthetic PrP peptides.

Structures of Purified $\operatorname{PrP}^{c}$ and $\operatorname{PrP}^{\mathrm{sc}}$. To gather evidence for or against the hypothesis that a conformational change features in $\mathrm{PrP}^{\mathrm{sc}}$ synthesis, we purified both $\mathrm{PrP}^{\mathrm{c}}$ and $\mathrm{PrP}^{\mathrm{sc}}$ using nondenaturing procedures and determined the secondary structure of each ${ }^{48,73)}$. Fourier transform infrared (FTIR) spectroscopy demonstrated that $\mathrm{PrP}^{\mathrm{c}}$ has a high $\alpha$-helix content (42\%) and no $\beta$-sheet (3\%), findings that were confirmed by circular dichroism measurements (Figure 2$)^{48)}$. In contrast, the $\beta$-sheet content of $\mathrm{PrP}^{\mathrm{sc}}$ was $43 \%$ and the $\alpha$-helix $30 \%$ as measured by FTIR. As determined in earlier studies, Nterminally truncated $\mathrm{PrP}^{\mathrm{Sc}}$ derived by limited proteolysis and designated $\operatorname{PrP} 27-30$ has an even higher $\beta$-sheet content (54\%) and a lower $\alpha$-helix $(21 \%)^{74-77)}$.

Neither purified $\operatorname{Pr}^{\mathrm{c}}$ nor $\mathrm{PrP}^{\mathrm{sc}}$ formed aggregates detectable by electron microscopy, while PrP 27-30 polymerized into rod-shaped amyloids (Figure 3 ). While these findings argue that the conversion of $\alpha$-helices into $\beta$-sheets underlies the formation of
$\mathrm{PrP}^{\mathrm{sc}}$, we cannot eliminate the possibility that an undetected chemical modification of a small fraction of $\mathrm{PrP}^{\mathrm{sc}}$ initiates this process. Since $\mathrm{PrP}^{\mathrm{sc}}$ seems to be the only component of the "infectious" prion particle, it is likely that this conformational transition is a fundamental event in the propagation of prions. In support of the foregoing statement is the finding that denaturation of $\operatorname{PrP} 27-30$ under conditions which reduced scrapie infectivity resulted in a concomitant diminution of $\beta$-sheet content 75,77).

Synthetic PrP Peptides. Peptides corresponding to the four putative $\alpha$-helical domains of SHaPrP were synthesized and contrary to predictions, three of the four spontaneously formed amyloids when dispersed into water, as shown by electron microscopy and Congo red staining ${ }^{69)}$. By infrared spectroscopy, these amyloid peptides were found to exhibit a secondary structure comprised largely of $\beta$-sheets, but formed $\alpha$-helices when dissolved in hexafluoroisopropanol. The first of the precicted helices is the 14-residue peptide corresponding to codons 109-122 ; this peptide, designated $\mathrm{H} 1$, and the overlapping 15-residue sequence 113-127 both form amyloid. The most highly amyloidogenic peptide is the sequence AGAAAGA corresponding to PrP codons 113-120. This peptide is in a region of $\operatorname{PrP}$ that is conserved across all known species.

Two other predicted $\alpha$-helices corresponding to 
codons 178-191 (H3) and 202-218 (H4) form amyloid and exhibit considerable $\beta$-sheet structure when synthesized as peptides.

Synthetic peptides corresponding to the region of $\mathrm{PrP}$ around $\mathrm{H} 1$ have been produced and their propensity to polymerize has been studied ${ }^{78-80)}$. Peptides differing by only a single amino acid at position 129 exhibit slowed amyloidogenesis when mixed together ${ }^{81)}$. Polymers of one synthetic PrP peptide have been found to be neurotoxic for primary cultures of hippocampal neurons ${ }^{82)}$.

\section{On the Mechanism of Conversion of $\operatorname{PrP}^{\mathrm{c}}$ into} $\operatorname{PrP}^{\mathrm{sc}}$. We and others have suggested that the conversion of $\mathrm{PrP}^{\mathrm{c}}$ into $\mathrm{PrP}^{\mathrm{sc}}$ may proceed through a metastable or partially unfolded intermediate designated PrP*, but no physical evidence for the existence of $\mathrm{PrP}^{*}$ has been obtained to date ${ }^{83,84)}$. Intermediates in the refolding of PrP 27-30 from a denatured state have been identified by fluorescence and CD spectroscopy ${ }^{85)}$. Experiments with immunoprecipitated $\left.{ }^{35} \mathrm{~S}-\right]$ Met labeled $\mathrm{SHaPrP}^{\mathrm{c}}$ and a $>50$-fold excess of purified SHaPrP 27-30 have been interpreted as showing that $\operatorname{PrP}^{\mathrm{c}}$ becomes protease resistant under these conditions ${ }^{86)}$. Why the results of experiments with radiolabeled $\mathrm{MoPrP} \mathrm{P}^{\mathrm{c}}$ as a negative control were not reported is unclear. Whether the protease resistance is due to the conversion of $\operatorname{PrP}^{\mathrm{c}}$ into $\mathrm{PrP}^{\mathrm{sc}}$ under these conditions, or it results from the binding of $\mathrm{PrP}^{\mathrm{c}}$ to $\mathrm{PrP}$ 27-30 which is quite hydrophobic, remains to be established. When the rations of $\operatorname{PrP}^{\mathrm{c}}$ and $\operatorname{PrP}^{\mathrm{sc}}$ approximate those found in vivo, no evidence for the conversion of $\mathrm{PrP}^{\mathrm{c}}$ into $\mathrm{PrP}^{\mathrm{sc}}$ could be found in cell free systems ${ }^{87)}$.

In studies with synthetic peptides, the hydrophobicity of $\mathrm{H} 1$ that seems to be primarily responsible for its amyloid-forming properties could be offset by extending the $\mathrm{N}$-terminus to include more hydrophilic residues. Longer peptides that contain Lys-104 and Lys-106 were found to be more stable as $\alpha$-helices or coils than in the $\beta$-sheet conformation (J. Nguyen, M. A. Baldwin, F. E. Cohen and S. B. Prusiner, in preparation). Ambiguity between coils and $\alpha$-helices is reminiscent of many nascent helices that have been characterized by 2D-NMR spectroscopy that form $\alpha$-helix in appropriate solvents only if an intrinsic helical propensity exists in the sequence. Both the SHaPrP peptide designated 104 $\mathrm{H} 1$, which extends from residue 104 to 122 , and peptide $\mathrm{H} 2$, which extends from residue 129 to 141 , provide substrates for monitoring conditions that might induce conformational changes that mirror those in $\mathrm{PrP}$. H2 is the only one of the four predicted helices that does not adopt $\beta$-sheet structure when synthesized as a peptide ${ }^{69)}$.

Non-covalent interactions between peptides from different regions of a protein have been shown to enhance secondary structure when the same structures in isolated peptides have only marginal stability. We found that $\mathrm{H} 2$ and $104 \mathrm{H} 1$ both adopt $\beta$-sheet structure when mixed with $\mathrm{H} 1$ in solvents favoring $\beta$-sheets. Thus, interactions in solution are able to promote the conformational transitions. As little as $1 \%$ (wt/wt) $\mathrm{H} 1$ in the mixture was sufficient to promote the conformational change detected in $\mathrm{H} 2$ or $104 \mathrm{H} 1$. We also compared the efficiency of the interactions between $\mathrm{SHa} 104 \mathrm{H} 1$ and $\mathrm{H} 1$ peptides corresponding to SHa and MoPrP sequences. The SHa and Mo sequences differ by two amino acids: SHaPrP encodes Met at residues 109 and 112 while MoPrP encodes Leu and Val, respectively. In 30\% acetonitrile, $\beta$-sheet is favored for both $\mathrm{SHaH} 1$ and $\mathrm{MoH} 1$, whereas SHa104H1 is largely coil. Over $24 \mathrm{~h}$, homotypic interactions between the two $\mathrm{SHa}$ peptides resulted in the progressive conversion of coils into $\beta$-sheets, while heterotypic interactions in a mixture of the $\mathrm{SHa}$ and Mo PrP peptides produced substantially less $\beta$-sheet (J. Nguyen, M. A. Baldwin, F. E. Cohen and S. B. Prusiner, in preparation). These findings support the concept that the species barrier for prions is due, at least in part, to inefficient interactions between PrP molecules having slightly different amino acid sequences.

The foregoing experiments with synthetic PrP peptides appear to model some of the unique characteristics of the conformational transition underlying the conversion of $\operatorname{PrP}^{\mathrm{c}}$ to $\mathrm{PrP}^{\mathrm{sc}}$. Although it is a formal possibility that an as yet undetecied covalent modification triggers a conformational transition in 
$\mathrm{PrP}^{\mathrm{c}}$ in vivo to form $\mathrm{PrP}^{\mathrm{sc}}$, these synthetic $\operatorname{PrP}$ peptides seem to undergo a similar transition in vitro without any apparent chemical change.

While the highly conserved $\mathrm{H} 1$ region of $\operatorname{PrP}$ is likely to be critical to the replication of prions, we have no information about its structure in $\mathrm{PrP}^{\mathrm{sc}}$. Considerable data argue that $\mathrm{PrP}^{\mathrm{sc}}$ in inoculated prions either induces a conformational transition in $\mathrm{PrP}^{\mathrm{c}}$ (template assistance) or interacts with low abundance intermediates (equilibrium assembly). Rarely does $\operatorname{PrP}^{\mathrm{C}}$ seem to transform spontaneously into $\mathrm{PrP}^{\mathrm{Sc}}$, as is probably the case in sporadic CJD. While the energy barriers to these conformational isomerizations may be relatively modest in isolated peptides, the equivalent processes for intact proteins in vivo may require the intervention of molecular chaperones. The concentration dependence of aggregation may further modify the details of the conformational interconversion of $\mathrm{PrP}^{\mathrm{c}}$ to $\mathrm{PrP}^{\mathrm{sc}}$. The enthalpic advantage of aggregation may be outweighed by adverse entropic factors at low concentration.

\section{No Evidence that Amyloid Formation Features in} PrP $^{\text {sc }}$ Synthesis. Some investigators have suggested that scrapie agent multiplication proceeds through a crystallization process involving $\mathrm{PrP}$ amyloid formation ${ }^{83,88-90)}$. While the high $\beta$-sheet content of $\mathrm{PrP}^{\mathrm{sc}}$ is clearly a hallmark distinguishing it from $\operatorname{PrP}^{\mathrm{c}}{ }^{48,76)}$, there is no evidence that $\operatorname{PrP}^{\mathrm{sc}}$ forms paracrystalline arrays as is the case for amyloids, which also have a high $\beta$-sheet content 91,92). Purified infectious prions isolated from scrapie-infected $\mathrm{SHa}$ brains with a cocktail of protease-inhibitors contain only $\mathrm{PrP}^{\mathrm{sc}}$ which exists as amorphous aggregates; only if $\operatorname{PrP}^{\mathrm{sc}}$ molecules are exposed to detergents and limited proteolysis, do they then polymerize into prion rods exhibiting the ultrastructural and tinctorial features of amyloid ${ }^{48,59)}$ (see Figure 3C). Furthermore, dispersion of prion rods into detergent-lipid-protein complexes results in a 10-to 100 -fold increase in scrapie titer, and no rods could be identified in these fractions by electron microscopy ${ }^{93)}$. Consistent with these findings is the absence or rarity of amyloid plaques in many prion diseases, as well as the inability to identify any amyloid-like polymers in cultured cells chronically synthesizing prions ${ }^{39,59)}$.

While prion replication seems to be "seeded" by $\mathrm{PrP}^{\mathrm{sc}}$, it can also be initiated by specific mutations, the specificity of which has been dramatically demonstrated recently when the change from a glutamate to a lysine at codon 200 produces $\mathrm{PrP}^{\mathrm{CJD}}$ and CJD in humans ${ }^{94)}$, while the same glutamate to lysine mutation at codon 219 is a common polymorphism occurring in $-6 \%$ of the Japanese population 95)

The specificity of prion replication has also been demonstrated in studies of $\mathrm{Tg}$ mice in which the prion produced is homologous to that in the inoculum ${ }^{39)}$. While $\mathrm{SHaPrP}^{\mathrm{c}}$ or a chimeric $\mathrm{SHa} /$ $\mathrm{MoPrP}^{\mathrm{c}}$ can be converted into the corresponding $\mathrm{PrP}^{\mathrm{sc}}$ molecules in $\mathrm{Tg}$ mice inoculated with $\mathrm{SHa}$ prions ${ }^{40)}$, the situation with $\mathrm{Hu}$ prions is different ${ }^{38)} \mathrm{Tg}(\mathrm{HuPrP})$ mice rarely produce $\mathrm{HuPrP}^{\mathrm{sc}}$ after inoculation with $\mathrm{Hu}$ prions while $\mathrm{Tg}$ (MHu2M) mice expressing a chimeric $\mathrm{Hu} / \mathrm{MoPrP} \mathrm{P}^{\mathrm{C}}$ readily produce chimeric $\mathrm{PrP}^{\mathrm{sc}}$ after inoculation with $\mathrm{Hu}$ prions. These results argue that a species-specific factor (s), possibly a chaperone-like molecule, is involved in the conversion of $\operatorname{PrP}^{\mathrm{C}}$ into $\operatorname{PrP}^{\mathrm{sc}}{ }^{38)}$.

It is difficult to reconcile the foregoing data with the conjecture that crystallization is the mechanism by which prions replicate. A crystallization phenomenon producing multidimensional macroscopic ordered arrays implies a high degree of at least twodimensional, and more commonly threedimensional, organization in aggregates of $\mathrm{PrP}^{\mathrm{sc}}$. It seems more likely that a complex process involving chaperones or similar molecules is responsible for transforming $\mathrm{PrP}^{\mathrm{c}}$ into $\mathrm{PrP}^{\mathrm{sc}}$.

\section{PRION PROPAGATION}

Mechanism of Prion Formation. Although the search for a scrapie-specific nucleic acid continues to be unrewarding, some investigators steadfastly cling to the notion that this putative polynucleotide drives prion replication. If prions are found to contain a scrapie-specific nucleic acid, then such a molecule would be expected to direct scrapie agent 


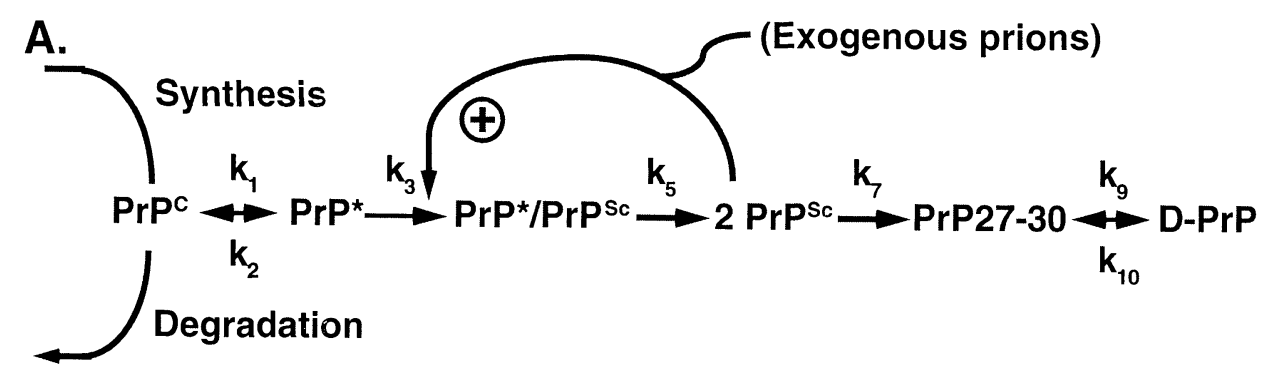

B.

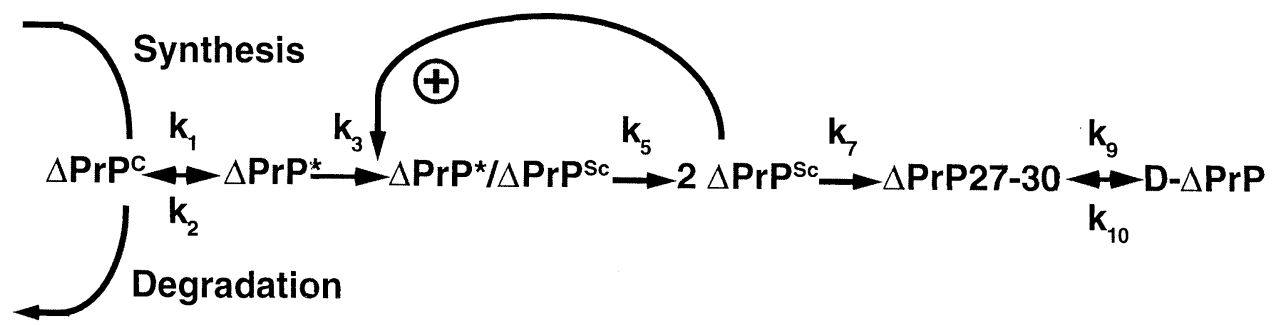

FIGURE 4

Models for the replication of prions. (A) Proposed scheme for the replication of prions in sporadic and infectious prion diseases. wtPrPc is synthesized and degraded as part of the normal metabolism of many cells. Stochastic fluctuations in the structure of $\operatorname{PrP}^{\mathrm{c}}$ can create $\left(\mathrm{k}_{1}\right)$ a rare, partially unfolded, monomeric structure, $\operatorname{PrP}^{*}$, that is an intermediate in the formation of $\operatorname{PrPsc}$, but can revert $\left(\mathrm{k}_{2}\right)$ to $\operatorname{PrP}^{\mathrm{c}}$ or be degraded prior to its conversion $\left(\mathrm{k}_{3}\right)$ into $\mathrm{PrP}^{\mathrm{sc}}$. Normally, the concentration of $\operatorname{PrP}^{*}$ is small and $\mathrm{PrP}^{\mathrm{sc}}$ formation is insignificant. In infectious prion diseases, exogenous prions enter the cell and stimulate conversion of $\mathrm{PrP}^{*}$ into $\mathrm{PrP}^{\mathrm{sc}}$. In the absence of exogenous prions, the concentration of $\mathrm{PrP}^{\mathrm{sc}}$ may eventually reach a threshold level in sporadic prion diseases after which a positive feedback loop would stimulate the formation of $\mathrm{PrP}^{\mathrm{sc}}$. Limited proteolysis of the $\mathrm{N}$-terminus of $\mathrm{PrP}^{\mathrm{sc}}$ produces $\left(\mathrm{k}_{5}\right) \operatorname{PrP}$ 27-30 which can also be generated in scrapie-infected cells from a recombinant vector encoding PrP truncated at the $\mathrm{N}$-terminus ${ }^{60}$. Denaturation $\left(\mathrm{k}_{7}\right)$ of $\operatorname{PrP}{ }^{\mathrm{sc}}$ or $\operatorname{PrP} 27-30$ renders these molecules protease sensitive and abolishes scrapie infectivity; attempts to renature $\left(\mathrm{k}_{8}\right)$ these $\operatorname{PrPsc}$ or PrP 27-30 have been unsuccessful to date ${ }^{7,10}$. (B) Scheme for the replication of prions in genetic prion diseases. Mutant $(\triangle) \operatorname{PrP}^{\mathrm{C}}$ is synthesized and degraded as part of the normal metabolism of many cells. Stochastic fluctuations in the structure of $\triangle \operatorname{PrP}^{\mathrm{c}}$ are increased compared to wtPrP ${ }^{\mathrm{c}}$, which creates $\left(\mathrm{k}_{1}\right)$ a partially unfolded, monomeric structure, $\triangle \operatorname{PrP}$, that is an intermediate in the formation of $\triangle \operatorname{PrPsc}$, but can revert $\left(\mathrm{k}_{2}\right)$ to $\triangle \operatorname{PrP}^{\mathrm{C}}$ or be degraded prior to its conversion $\left(\mathrm{k}_{3}\right)$ into $\triangle \operatorname{Pr}^{\mathrm{sc}}$. Limited proteolysis of the $\mathrm{N}$-terminus of $\triangle \operatorname{Pr} \mathrm{P}^{s c}$ produces $\left(\mathrm{k}_{5}\right) \triangle \operatorname{PrP} 27-30$ which in some cases may be less protease resistant than wtPrP $27-30^{101,194)}$. Adapted from ${ }^{84)}$.

replication using a strategy similar to that employed by viruses. In the absence of any chemical or physical evidence for a scrapie-specific polynucleotide, it seems reasonable to consider some alternative mechanisms that might feature in prion biosynthesis. The multiplication of prion infectivity is an exponential process in which the posttranslational conversion of $\operatorname{PrP}^{\mathrm{c}}$ or a precursor to $\mathrm{PrP}^{\mathrm{Pc}}$ appears to be obligatory ${ }^{27)}$.

Stochastic fluctuations in the structure of $\mathrm{PrP}^{\mathrm{c}}$ can create a rare, partially unfolded, monomeric structure, $\operatorname{PrP}^{*}$, that is an intermediate in the formation of $\mathrm{PrP}^{\mathrm{sc}}$, but can revert to $\mathrm{PrP}^{\mathrm{c}}$ or be degraded prior to its conversion into $\operatorname{PrP}^{\mathrm{sc}}$ (Figure 4) ${ }^{84)}$. Normally, the concentration of $\operatorname{PrP}^{*}$ is small and $\mathrm{PrP}^{\mathrm{sc}}$ formation is insignificant. Whether $\mathrm{PrP}^{\mathrm{sc}}$ formation involves oligomerization remains uncertain, since the insolubility of $\mathrm{PrP}^{\mathrm{sc}}$ has precluded analysis of its physical state ${ }^{93)}$.

Infection with exogenous prions containing $\mathrm{PrP}^{\mathrm{sc}}$ 
Table 1. Human prion diseases

\begin{tabular}{ll}
\hline Disease & Etiology \\
\hline Kuru & Infection \\
Creutzfeldt-Jakob disease & \\
$\quad$ latrogenic & Infection \\
Sporadic & Unknown \\
Familial & PrP mutation \\
Gerstmann-Straussler-Scheinker disease & PrP mutation \\
Fatal Familial Insomnia & PrP mutation \\
\hline
\end{tabular}

Table 2. Evidence that $\operatorname{PrP}^{\mathrm{sc}}$ is a major and essential component of the infectious prion

1. Copurification of $\operatorname{PrP} 27-30$ and scrapie infectivity by biochemical methods. Concentration of $\operatorname{PrP} 27-30$ is proportional to prion titer ${ }^{73,176-181)}$.

2. Kinetics of proteolytic digestion of $\operatorname{PrP} 27-30$ and infectivity are similar ${ }^{176-178)}$.

3. Copurification of $\operatorname{PrP}^{\mathrm{sc}}$ and infectivity by immunoaffinity chromatography. $\alpha$-PrP antisera neutralization of infectivity ${ }^{182,183)}$.

4. $\operatorname{PrP}{ }^{\mathrm{sc}}$ detected only in clones of cultured cells producing infectivity ${ }^{61,62,184)}$.

5. PrP amyloid plaques are specific for prion diseases of animals and humans ${ }^{185-188}$. Deposition of PrP amyloid is controlled, at least in part, by the PrP sequence ${ }^{39}$.

6. $\operatorname{Pr} P^{s c}$ (or $\operatorname{Pr}^{\mathrm{CJD}}$ ) is specific for prion diseases of animals and humans ${ }^{189-191}$ ). Deposition of $\operatorname{Pr} P^{\mathrm{sc}}$ precedes spongiform degeneration and reactive gliosis ${ }^{121,139,154,155)}$.

7. Genetic linkage between the $\operatorname{PrP}$ gene and scrapie incubation times in mice with short and long incubation times ${ }^{144-146,192)}$ encoding PrP molecules differing at residues 108 and $189^{148)}$. The length of the incubation time is determined by the level of $\operatorname{PrP}$ expression and the PrP sequence ${ }^{121}$.

8. Expression of $\mathrm{SHaPrP}$ in $\mathrm{Tg}(\mathrm{SHaPrP})$ mice renders them susceptible to SHa prions ${ }^{114)}$.

The primary structure of $\operatorname{PrP}^{\mathrm{Ps}}$ in the inoculum governs the neuropathology and prin synthesis ${ }^{39}$. Expression of a chimeric $\mathrm{PrP}$ in $\mathrm{Tg}$ (MHu2M) mice renders them susceptible to Hu prions ${ }^{38}$.

9. Genetic linkage between PrP gene point mutations at codons 102, 178, 198 or 200 and the development of inherited prion diseases in humans was demonstrated ${ }^{18,94,103,104)}$.

Genetic linkage was also established between the mutation insert of six additional octarepeats and familial CJD 105).

10. Mice expressing MoPrP transgenes with the P102L point mutation of GSS spontaneously develop neurologic dysfunction, spongiform brain degeneration, and astrocytic gliosis ${ }^{36}$.

Serial transmission of neurodegeneration was initiated with brain extracts from these Tg mice.

11. Ablation of the $\operatorname{PrP}$ gene in mice prevents scrapie and propagation of prions after intracerebral inoculation of prions. ${ }^{8,9)}$.

12. Mice expressing chimeric Mo/SHaPrP transgenes produce "artificial" prions with novel properties ${ }^{40)}$.

13. Overexpression of MoPrP-B and SHaPrP produces spongiform degeneration, myopathy and peripheral neuropathy in older transgenic mice; serial transmission of neurodegeneration was initiated with brain extracts ${ }^{28)}$.

would act as a template to promote the conversion of $\mathrm{PrP}^{*}$ into $\mathrm{PrP}^{\mathrm{Sc}}$ (Figure 4A) . The insolubility of $\mathrm{PrP}^{\mathrm{sc}}$ would make this process irreversible and drive the formation of $\mathrm{PrP}^{*}$ as well $\mathrm{PrP}^{\mathrm{sc}}$ by mass action. Examples of prion infection include: kuru caused by ritualistic cannibalism among the Fore people of New Guinea, CJD in young adults treated with prion-contaminated growth hormone extracted from human pituitaries, and "mad cow" disease caused by prion-contaminated meat and bone meal prepared from the offal of scrapied sheep or "mad" cattle ${ }^{12,96,97)}$. 
The sporadic prion diseases might result from the relatively infrequent accumulation of sufficient $\mathrm{PrP}^{*}$ to produce $\mathrm{PrP}^{\mathrm{sc}}$ (Figure 4A) . In support of this proposal are $\mathrm{Tg}$ mice overexpressing wtPrP that develop spongiform degeneration and produce prions in their brains ${ }^{28)}$. Alternatively, somatic mutations might destabilize $\mathrm{PrP}^{\mathrm{c}}$ which would promote its conversion into $\mathrm{PrP}^{*}$. Of note is the common polymorphism encoding Met or $\mathrm{Val}$ at codon 129 in human $\operatorname{PrP}$ which lies at the $\mathrm{N}$-terminal border of second putative $\alpha$-helix in $\operatorname{PrP}^{\mathrm{C}}$ (Figure 4 B) but may be at the end of a $\beta$-strand in $\operatorname{PrP}^{\mathrm{sc}} 70$ ) That homozygosity at codon 129 appears to predispose to sporadic CJD ${ }^{98)}$ is intriguing since this residue could lie at a multimeric interface joining two $\beta$-sheets. Studies of other proteins suggest that Met-Met and Val-Val are common neighbors in $\beta$-sheets and Met-Val are distinctly unusual ${ }^{99)}$. Patients with the D178N mutation present with insomnia if codon 129 encodes Met on the mutant allele or dementia if codon 129 encodes Val ${ }^{100,101)}$.

Homophilic Interactions. The results of transgenetic studies argue that $\mathrm{PrP}^{\mathrm{Sc}}$ combines with $\mathrm{PrP}^{*}$ or $\mathrm{PrP}^{\mathrm{C}}$ to form a transient complex which is subsequently transformed into two molecules of $\mathrm{PrP}^{\mathrm{sc}}$ (Figure 4A) ${ }^{39)}$. In the next cycle, two $\mathrm{PrP}^{\mathrm{sc}}$ molecules combine with two $\mathrm{PrP}^{*}$ or $\mathrm{PrP}^{\mathrm{c}}$ molecules giving rise to two complexes that dissociate to combine with four $\mathrm{PrP}^{*}$ or $\mathrm{PrP}^{\mathrm{c}}$ molecules creating an exponential process. As noted above, $\mathrm{PrP}^{\mathrm{sc}}$ formation may involve oligomerization but the insolubility of $\mathrm{PrP}^{\mathrm{sc}}$ has precluded determination of the stoichiometry ${ }^{93)}$. If prion biosynthesis simply involved amplification of post-translationally modified PrP molecules, we might expect Tg (SHa$\mathrm{PrP}$ ) mice to produce both SHa and Mo prions after inoculation with either prion, since these mice produce SHa and MoPrPc . Yet Tg ( $\mathrm{SHaPrP}$ ) mice synthesize only those prions present in the inoculum (see below, Figures $5 \mathrm{E}$ and $5 \mathrm{~F}$ ). These results contend that the incoming prion and $\mathrm{PrP}^{\mathrm{sc}}$ interact with the homologous $\mathrm{PrP}^{*}$ or $\mathrm{PrP}^{\mathrm{c}}$ substrate to replicate more of the same prions (Figure 4A) .

Additional evidence in support of the proposed model for prion replication comes from $\mathrm{Tg}$ (Mo/ $\mathrm{SHaPrP})$ mice expressing chimeric $\mathrm{Mo} / \mathrm{SHaPrP}^{\mathrm{c}}$ ${ }^{40)}$. The chimeric Mo/SHaPrP gene was constructed by substituting the $\mathrm{SHaPrP}$ sequence for $\mathrm{MoPrP}$ from codon 94 to 188 ; within this domain, there are five amino acid substitutions which distinguish Mo from SHaPrP. When inoculated with either Mo or SHa prions, these $\mathrm{Tg}(\mathrm{Mo} / \mathrm{SHaPrP})$ mice develop scrapie after $\sim 140$ days. The chimeric $\mathrm{Tg}$ mice produce $\mathrm{Mo} / \mathrm{SHaPrP}^{\mathrm{sc}}$ and $\mathrm{Mo} / \mathrm{SHa}$ prions after inoculation with $\mathrm{SHa}$ prions and probably $\mathrm{Mo}$ prions as well. Evidence for chimeric $\mathrm{Mo} / \mathrm{SHa}$ prions comes from the development of scrapie in $\mathrm{Tg}$ $(\mathrm{Mo} / \mathrm{SHaPrP})$ mice $\sim 70$ days after inoculation with brain extracts from $\mathrm{Tg}(\mathrm{Mo} / \mathrm{SHaPrP})$ mice containing the chimeric prions.

Because mice expressing HuPrP transgenes have not had abbreviated incubation times similar to $\mathrm{Tg}$ $(\mathrm{SHaPrP})$ mice when inoculated with homologous prions, we constructed a chimeric $\mathrm{Hu} / \mathrm{Mo}$ transgene similar to the chimeric MH2M transgene. $\mathrm{Hu}$ PrP differs from mouse $\operatorname{PrP}$ at 28 of 254 positions ${ }^{102)}$ while chimeric $\mathrm{Hu} / \mathrm{Mo}$ PrP, designated MHu2M differs at nine residues. Mice expressing the MHu2 $\mathrm{M}$ transgene are susceptible to human prions and exhibit abbreviated incubation times ${ }^{38)}$. These findings argue that a mouse-specific factor that we have provisionally designated protein $\mathrm{X}$ forms a ternary complex with $\mathrm{PrP}^{\mathrm{c}}$ and $\mathrm{PrP}^{\mathrm{sc}}$ during the formation of nascent $\mathrm{PrP}^{\mathrm{sc}}$. Failure to produce nascent $\mathrm{PrP}^{\mathrm{sc}}$ when $\operatorname{PrP}^{\mathrm{sc}}$ is mixed with $\operatorname{Pr}^{\mathrm{C}}{ }^{\mathrm{87}}$ ) also argues for another factor such as protein $\mathrm{X}$. Whether protein $\mathrm{X}$ is a chaperone that is involved in catalyzing the conformational changes that feature in the formation of $\mathrm{PrP}^{\mathrm{sc}}{ }^{48)}$, remains to be established. One possible explanation for the difference in susceptibility of $\mathrm{Tg}$ (MHu2M) and $\mathrm{Tg}(\mathrm{HuPrP})$ mice to $\mathrm{Hu}$ prions is that mouse chaperones catalyzing the refolding of $\mathrm{PrP}^{\mathrm{c}}$ into $\mathrm{PrP}^{\mathrm{sc}}$ can readily interact with the MHu2MPrP $\mathrm{P}^{\mathrm{C}} / \mathrm{HuPr} \mathrm{P}^{\mathrm{CJD}}$ complex but not with $\mathrm{HuPrP} / \mathrm{HuPrP} \mathrm{P}^{\mathrm{c} D}$.

\section{Conversion of $\operatorname{PrP} \alpha$-Helices into $\beta$-Sheets.}

Numerous investigations described above have been directed toward finding a scrapie-specific nucleic 
A.

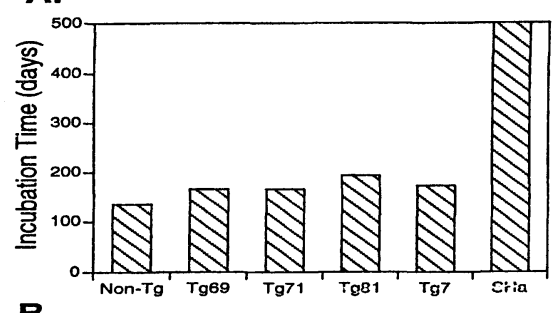

B.

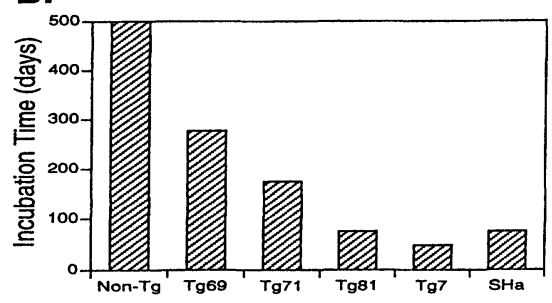

C.

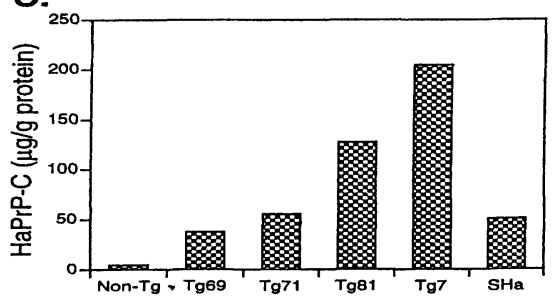

D.

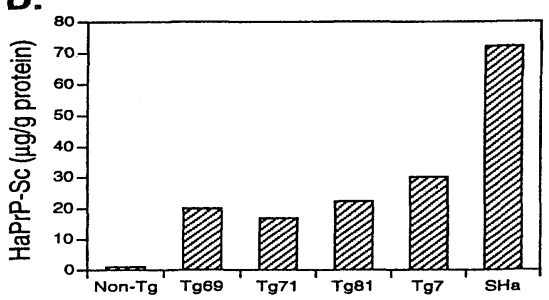

E.

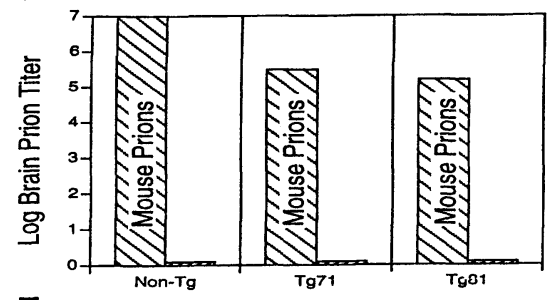

F.

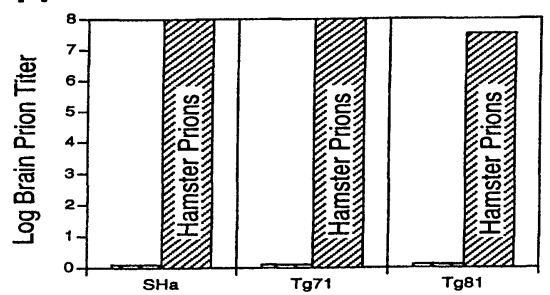

G.

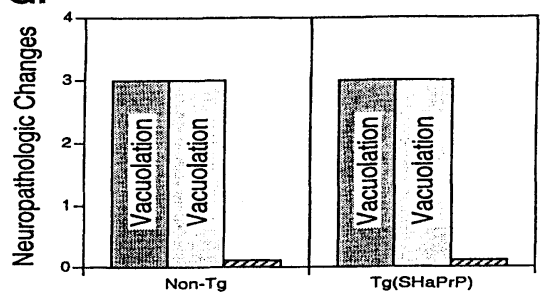

H.

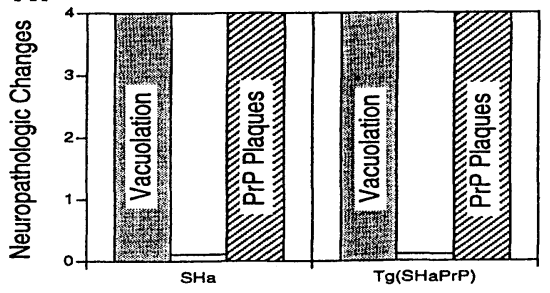

FIGURE 5

Transgenic $(\mathrm{Tg})$ mice expressing Syrian hamster $(\mathrm{SHa})$ prion protein exhibit species-specific scrapie incubation times, infectious prion synthesis and neuropathology ${ }^{39}$. (A) Scrapie incubation times in non-transgenic mice (Non-Tg) and four lines of Tg mice expressing SHaPrP and Syrian hamsters inoculated intracerebrally with $\sim 10^{6} \mathrm{ID}_{50}$ units of Chandler Mo prions serially passaged in Swiss mice. The four lines of $\mathrm{Tg}$ mice have different numbers of transgene copies: Tg69 and 71 mice have two to four copies of the SHaPrP transgene, whereas Tg81 have 30 to 50 and $\mathrm{Tg} 7$ mice have $>60$. Incubation times are number of days from inoculation to onset of neurologic dysfunction. (B) Scrapie incubation times in mice and hamsters inoculated with $\sim 10^{7} \mathrm{ID}_{50}$ units of Sc237 prions serially passaged in Syrian hamsters and as described in (A). (C) Brain $\mathrm{SHaPrP}^{\mathrm{C}}$ in Tg mice and hamsters. SHaPrPc levels were quantitated by an enzyme-linked immunoassay. (D) Brain SHaPrP $\mathrm{Sc}^{\mathrm{sc}}$ in $\mathrm{Tg}$ mice and hamsters. Animals were killed after exhibiting clinical signs of scrapie. SHaPrPsc levels were determined by immunoassay. (E) Prion titers in brains of clinically ill animals after inoculation with Mo prions. Brain extracts from Non-Tg, Tg71, and Tg81 mice were bioassayed for prions in mice (left) and hamsters (right). (F) Prion titers in brains of clinically ill animals after inoculation with SHa prions. Brain extracts from Syrian hamsters as well as $\mathrm{Tg} 71$ and $\mathrm{Tg} 81$ mice were bioassayed for prions in mice (left) and hamsters (right). (G) Neuropathology in Non- $\mathrm{Tg}$ mice and $\mathrm{Tg}(\mathrm{SHaPrP})$ mice with clinical signs of scrapie after inoculation with Mo prions. Vacuolation in grey (left) and white matter

(center) ; PrP amyloid plaques (right). Vacuolation score: $0=$ none, $1=$ rare, $2=$ modest, $3=$ moderate, $4=$ intense. (H) Neuropathology in Syrian hamsters and transgenic mice inoculated with SHa prions. Degree of vacuolation and frequency of PrP amyloid plaques as described in (G). Adapted from $^{11}$. 
acid, without success. In contrast, there has been a compelling convergence of data implicating $\mathrm{PrP}^{\mathrm{sc}}$ in the transmission and pathogenesis of prion diseases

(Table 2). Since studies of $\mathrm{PrP}^{\mathrm{sc}}$ failed to reveal a candidate post-translational chemical modification that might distinguish it from $\operatorname{PrP}^{\mathrm{c}}{ }^{47)}$, the secondary structures of $\mathrm{PrP}^{\mathrm{c}}$ and $\mathrm{PrP}^{\mathrm{sc}}$ were determined ${ }^{48)}$. As described above, FTIR spectroscopy demonstrated that $\operatorname{PrP}^{\mathrm{C}}$ has a high $\alpha$-helix and low $\beta$ sheets content (Figure 2), findings that were confirmed by circular dichroism measurements ${ }^{48)}$. In contrast, the $\beta$-sheet content of $\mathrm{PrP}^{\mathrm{sc}}$ was more than $40 \%$ and the $\alpha$-helix $30 \%$ as measured by FTIR. While these findings argue that the conversion of $\alpha$-helices into $\beta$-sheets underlies the formation of both $\mathrm{PrP}^{\mathrm{sc}}$ and infectious prions, we cannot eliminate the possibility that an undetected chemical modification of a small fraction of $\mathrm{PrP}^{\mathrm{sc}}$ initiates this process.

Mutant PrP Molecules. In humans carrying point mutations or inserts in their PrP genes (see below, Figure 6), mutant $\mathrm{PrP}^{\mathrm{C}}$ molecules might spontaneously convert into $\mathrm{PrP}^{\mathrm{sc}}$ (Figure 4B). Eleven point mutations and seven inserts composed of different numbers of tandemly repeated octamers in $\operatorname{PrP}$ have been found to segregate with inherited prion diseases ; five mutations have occurred in families sufficiently large to establish genetic linkage ${ }^{18,94}$. ${ }^{103-105)}$. Ten of 11 point mutations are located within or near the four $\alpha$-helices, and thus cluster around a central core region that is essential for the structural stability of $\operatorname{PrP}^{\mathrm{c}}{ }^{70}$. The tertiary structural model of $\mathrm{PrP}^{\mathrm{c}}$ was generated by examining all plausible spatial arrangements for the $\alpha$-helices in this putative four-helix bundle protein. Presumably, $\operatorname{PrP}$ mutations $(\triangle)$ destabilize $\triangle \operatorname{PrP}^{\mathrm{C}}$ and promote its conversion into $\triangle \mathrm{PrP}^{*}$ which results in the formation of $\triangle \operatorname{PrP}^{\mathrm{sc}}(\text { Figure } 4 \mathrm{~B})^{84)}$. While the initial stochastic event may be inefficient, once it happens the process becomes autocatalytic.

The proposed mechanism for prion replication in genetic prion diseases is consistent with individuals harboring germline mutations who do not develop CNS dysfunction for decades and with studies on $\mathrm{Tg}$
(MoPrP-P101L) H mice that spontaneously develop CNS degeneration ${ }^{36,37)}$. Whether all GSS and familial CJD cases contain infectious prions, or some represent inborn errors of PrP metabolism in which neither $\mathrm{PrP}^{\mathrm{sc}}$ nor prion infectivity accumulates, is unknown; however, transmission of inherited human prion diseases to rodents is less frequent than for sporadic CJD ${ }^{22)}$. In contrast, transmission of inherited prion diseases to apes and monkeys seems to be only slightly less efficient than from sporadic or iatrogenic cases ${ }^{106)}$. The use of $\mathrm{Tg}$ (MHu2M) mice will allow more detailed studies of the transmission of the inherited human prion diseases to experimental hosts and should clarify some the unresolved issues surrounding mutant $\operatorname{PrP}^{\mathrm{C}}$ molecules and their role in the pathogenesis of CNS degeneration ${ }^{38)}$.

\section{TRANSGENETICS AND GENE TARGETING}

While transgenetic studies have yielded a wealth of new knowledge about infectious, genetic and sporadic prion diseases, the laborious production of $\mathrm{Tg}$ mice limits the number of studies that can be performed. The relatively long gestation period of mice coupled with the need to do microinjections of fertilized embryos prevents the creation of the very large numbers of different $\mathrm{Tg}$ mice that would yield the greatest amount of new information. Assays that permit screening of a multitude of possible phenotypes in genetic experiments are generally the most informative. While the limited number of mice expressing different transgenes is definitely a liability, experiments with $\mathrm{Tg}$ mice expressing foreign and mutant PrP molecules have been extraordinarily useful in advancing our understanding of prion biology. It is important to stress that transgenetic studies can readily yied an incomplete, and sometimes erroneous interpretation of the data if the number of lines of mice examined expressing a particular construct is inadequate. Defining an adequate number of lines is difficult but certainly comparisons of lines expressing high and low levels of a given $\mathrm{PrP}$ transgene have proved to be quite helpful 37.39). 
Table 3. Species-specific prion inocula determine the distribution of spongiform change and deposition of $\operatorname{PrP}$ amyloid plaques in transgenic mice

\begin{tabular}{|c|c|c|c|c|c|c|c|c|c|}
\hline \multirow{3}{*}{ Animal } & \multicolumn{5}{|c|}{ SHa prions } & \multicolumn{4}{|c|}{ Mo prions } \\
\hline & \multirow[b]{2}{*}{$\mathrm{n}^{\mathrm{c}}$} & \multicolumn{2}{|c|}{$\begin{array}{l}\text { Spongiform } \\
\text { change }^{\mathrm{a}}\end{array}$} & \multicolumn{2}{|c|}{$\begin{array}{c}\text { PrP } \\
\text { plaques }^{b}\end{array}$} & \multirow[b]{2}{*}{$\mathrm{n}^{\mathrm{c}}$} & \multicolumn{2}{|c|}{$\begin{array}{l}\text { Spongiform } \\
\text { change }^{\mathrm{a}}\end{array}$} & \multirow{2}{*}{$\begin{array}{c}\begin{array}{c}\text { PrP } \\
\text { plaques }^{6}\end{array} \\
\text { Frequency }\end{array}$} \\
\hline & & Gray & Wht & Frequency & Diameter $^{\mathrm{d}}$ & & Gray & Wht & \\
\hline Non- $\mathrm{Tg}$ & & N.D. ${ }^{e}$ & & N.D. & & 10 & + & + & - \\
\hline $\operatorname{Tg} 69$ & 6 & $+^{\mathrm{f}}$ & - & Numerous & $6.5 \pm 3.1 \quad(389)$ & 2 & + & + & - \\
\hline $\operatorname{Tg} 71$ & 5 & + & - & Numerous & $8.1 \pm 3.6$ & 2 & + & + & - \\
\hline $\operatorname{Tg} 81$ & 7 & + & - & Numerous & $8.3 \pm 3.0$ & 3 & + & + & Few \\
\hline $\operatorname{Tg} 7$ & 3 & $+^{8}$ & - & Numerous & $14.0 \pm 8.3$ & 4 & + & + & - \\
\hline Sha & 3 & + & - & Numerous & $5.7 \pm 2.7$ & & N.D. & & N.D. \\
\hline
\end{tabular}

a Spongiform change evaluated in hippocampus, thalamus, cerebral cortex and brainstem for gray matter and the deep cerebellum for white matter.

b Plaques in the subcallosal region were stained with $\mathrm{SHaPrP} m A b$ 13A5, anti-PrP rabbit antisera R073 and trichrome stain.

c $n=$ number of brains examined.

d Mean diameter of PrP plaques given in microns \pm standard error with the number of observations in parentheses.

e N.D. = not determined.

$\mathrm{f}+=$ present ; - = not found.

g Focal: confirmed to the dorsal nucleus of the raphe.

Source : From ${ }^{193}$.

\section{Species Barriers for Transmission of Prion Dis-}

eases. The passage of prions between species is a stochastic process characterized by prolonged incubation times 107-109). Prions synthesized de novo reflect the sequence of the host $\operatorname{PrP}$ gene and not that of the $\mathrm{PrP}^{\mathrm{sc}}$ molecules in the inoculum ${ }^{110)}$. On subsequent passage in a homologous host, the incubation time shortens to that recorded for all subsequent passages and it becomes a nonstochastic process. The species barrier concept is of practical importance in assessing the risk for humans of developing CJD after consumption of scrapieinfected lamb or BSE-infected beef ${ }^{46,66,111-113)}$.

To test the hypothesis that differences in $\operatorname{Pr} P$ gene sequences might be responsible for the species barrier, Tg mice expressing $\mathrm{SHaPrP}$ were constructed ${ }^{39,114)}$. The PrP genes of Syrian hamsters and mice encode proteins differing at 16 positions. Incubation times in four lines of $\mathrm{Tg}(\mathrm{SHaPrP})$ mice inoculated with Mo prions were prolonged compar- ed to those observed for non-Tg, control mice (Figure 5A) . Inoculation of $\mathrm{Tg}(\mathrm{SHaPrP})$ mice with SHa prions demonstrated abrogation of the species barrier resulting in abbreviated incubation times due to a nonstochastic process (Figure 5 B) ${ }^{39,114)}$. The length of the incubation time after inoculation with $\mathrm{SHa}$ prions was inversely proportional to the level of $\mathrm{SHaPrP}^{\mathrm{c}}$ in the brains of $\mathrm{Tg}$ ( $\mathrm{SHaPrP})$ mice (Figures 5B and 5C) ${ }^{39}$. $\mathrm{SHaPrP}^{\mathrm{sc}}$ levels in the brains of clinically ill mice were similar in all four $\mathrm{Tg}$ ( $\mathrm{SHaPrP}$ ) lines inoculated with $\mathrm{SHa}$ prions (Figure 5D). Bioassays of brain extracts from clinically ill $\mathrm{Tg}(\mathrm{SHaPrP})$ mice inoculated with Mo prions revealed that only Mo prions but no $\mathrm{SHa}$ prions were produced (Figure 5E). Conversely, inoculation of $\mathrm{Tg}$ ( $\mathrm{SHaPrP})$ mice with $\mathrm{SHa}$ prions led to only the synthesis of SHa prions (Figure $5 \mathrm{~F}$ ). Thus, the de novo synthesis of prions is species specific and reflects the genetic origin of the inoculated prions. Similarly, the neuropathology of $\mathrm{Tg}(\mathrm{SHaPrP})$ mice is determined by the genetic 


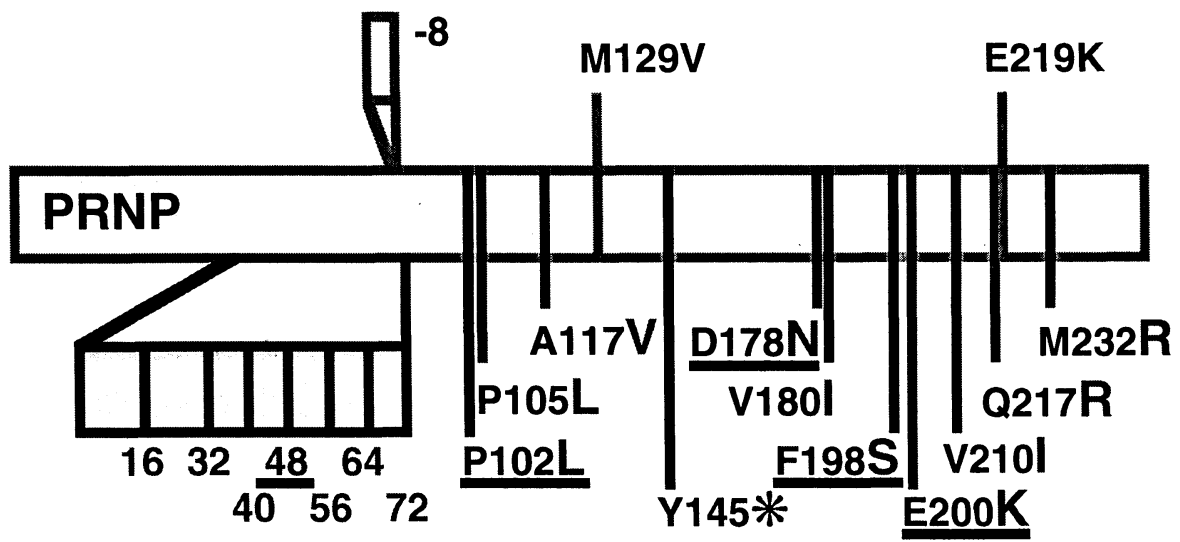

Octarepeat Sequence $P(Q / H) G G G(G /-) W G Q$

\section{Genetic Linkage}

FIGURE 6

Human prion protein gene (PRNP). The open reading frame (ORF) is denoted by the large gray rectangle. Human PRNP wild-type polymorphisms are shown above the recctangle while mutations that segregate with the inherited prion diseases are depicted below. The wild-type human PrP gene contains five octarepeats [P (Q/H) GGG (G/-) WGQ] from codons 51 to $91^{102)}$. Deletion of a single octarepeat at codon 81 or 82 is not associated with prion disease ${ }^{195-197)}$; whether this deletion alters the phenotypic characteristics of a prion disease is unknown. There are common polymorphisms at codons $117(\mathrm{Ala} \rightarrow \mathrm{Val}$ ) and 129 (Met $\rightarrow \mathrm{Val})$; homozygosity for Met or Val at codon 129 appears to increase susceptibility to sporadic CJD ${ }^{98}$ ). Octarepeat inserts of $16,32,40,48,56,64$, and 72 amino acids at codons 67,75 or 83 are designated by the small rectangle below the ORF. These inserts segregate with familial CJD, and genetic linkage has been demonstrated where sufficient specimens from family members are available ${ }^{198-205)}$. Point mutations are designated by the wild-type amino acid preceding the codon number and the mutant residue follows, e. g., P102L. These point mutations segregate with the inherited prion diseases and significant genetic linkage (underlined mutations) has been demonstrated where sufficient specimens from family members are available. Mutations at codons $102(\mathrm{Pro} \rightarrow \mathrm{Leu}), 117(\mathrm{Ala} \rightarrow \mathrm{Val}), 198(\mathrm{Phe} \rightarrow \mathrm{Ser})$ and $217(\mathrm{Gln} \rightarrow \mathrm{Arg})$ are found in patients with GSS $18,33,103,206-212)$. Point mutations at codons $178(\mathrm{Asp} \rightarrow \mathrm{Asn}), 200(\mathrm{Glu} \rightarrow \mathrm{Lys})$ and $210(\mathrm{Val} \rightarrow 1 \mathrm{le})$ are found in patients with familial CJD ${ }^{213-217}$. Point mutations at codons 198 (Phe $\rightarrow$ Ser) and 217 (Gln $\rightarrow$ Arg) are found in patients with GSS who have PrP amyloid plaques and neurofibrillary tangles ${ }^{103,218)}$. Additional point mutations at codons $145(\mathrm{Tyr} \rightarrow$ Stop), $105(\mathrm{Pro} \rightarrow \mathrm{Leu}), 180(\mathrm{Val} \rightarrow 1 \mathrm{le})$ and 232 (Met $\rightarrow$ Arg) have been recently reported ${ }^{219,220)}$. Single letter code for amino acids is as follows: A, Ala; D, Asp ; E, Glu; F, Phe; I, lle; K, Lys; L, Leu; M, Met ; N, Asn; P, Pro ; Q, Gln; R, Arg; S, Ser; T, Thr; and V, Val; Y, Tyr.

origin of prion inoculum. Mo prions injected into Tg

(SHaPrP) mice produced a neuropathology characteristic of mice with scrapie. A moderate degree of vacuolation in both the gray and white matter was found while amyloid plaques were rarely detected (Figure 5G) (Table 3). Inoculation of $\mathrm{Tg}$ (SHaPrP) mice with SHa prions produced intense vacuolation of the gray matter, sparing of the white matter, and numerous $\mathrm{SHaPrP}$ amyloid plaques characteristic of Syrian hamsters with scrapie (Figure $5 \mathrm{H}$ ) .
Overexpression of wtPrP Transgenes. During transgenetic studies, we discovered that uninoculated older mice harboring high copy-numbers of wtPrP transgenes derived from Syrian hamsters, sheep, and PrP-B mice spontaneously developed truncal ataxia, hind-limb paralysis and tremors ${ }^{68)}$. These Tg mice exhibited a profound necrotizing myopathy involving skeletal muscle, a demyelinating polyneuropathy and focal vacuolation of the CNS. 


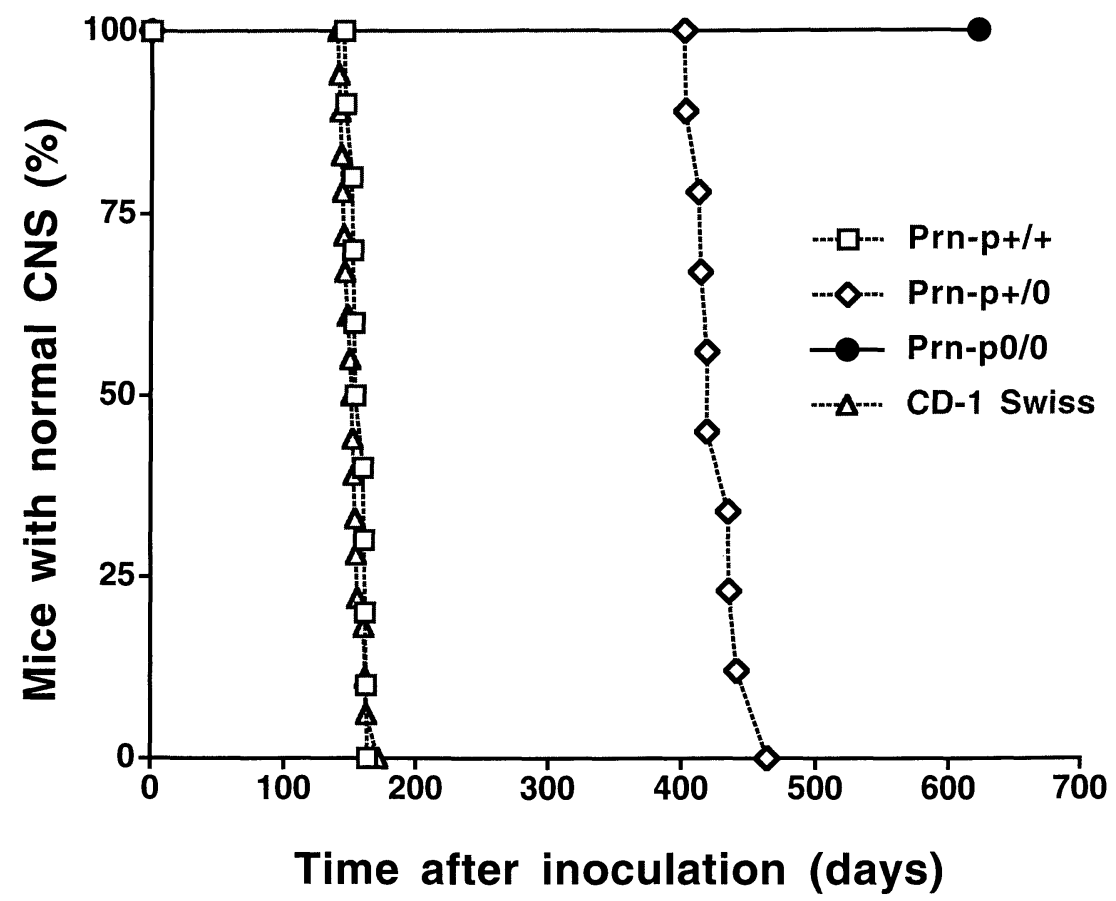

FIGURE 7

Incubation times in PrP gene ablated Prn- $\mathrm{p}^{0 /+}$ and Prn- $\mathrm{p}^{0 / 0}$ mice as well as wt Prn- $\mathrm{p}^{+/+}$and CD-1 mice inoculated with RML mouse prions. The RML prions were heated and irradiated at $254 \mathrm{~nm}$ prior to intracerebral inoculation into CD-1 Swiss mice (open triangles), Prn- $\mathrm{p}^{+/+}$mice (open squares), Prn- $\mathrm{p}^{0 /+}$ mice (open diamonds) or Prn- $\mathrm{p}^{0 / 0}$ mice (filled circle) .

Development of disease was dependent on transgene dosage. For example, Tg $\left(\mathrm{SHaPrP}^{+/+}\right) 7$ mice homozygous for the SHaPrP transgene array regularly developed disease between 400 and 600 days of age, while hemizygous $\mathrm{Tg}\left(\mathrm{SHaPrP}^{+10}\right) 7$ mice also developed disease, but after $>650$ days.

Attempts to demonstrate $\mathrm{PrP}^{\mathrm{sc}}$ in either muscle or brain were unsuccessful but transmission of disease with brain extracts from $\mathrm{Tg}\left(\mathrm{SHaPrP}^{+/+}\right)$ 7 mice inoculated into Syrian hamsters did occur. These Syrian hamsters had $\mathrm{PrP}^{\mathrm{sc}}$ as detected by immunoblotting and spongiform degeneration (D. Groth and S. B. Prusiner, unpublished data). Serial passage with brain extracts from these animals to recipients was observed. De novo synthesis of prions in $\mathrm{Tg}\left(\mathrm{SHaPrP}^{+1+}\right) 7$ mice overexpressing wtSHaPrPc provides support for the hypothesis that sporadic CJD does not result from infection but rather is a consequence of the spontaneous, although rare, conversion of $\operatorname{Pr}^{\mathrm{c}}$ into $\mathrm{PrP}^{\mathrm{sc}}$. Alternatively, a somatic mutation in which mutant
$\mathrm{SHaPrP}^{\mathrm{c}}$ is spontaneously converted into $\mathrm{PrP}^{\mathrm{sc}}$ as in the inherited prion diseases could also explain sporadic CJD. These findings as well as those described below for Tg (MoPrP-P101L) mice argue that prions are devoid of foreign nucleic acid, in accord with many earlier studies that use other experimental approaches as described above.

\footnotetext{
Ablation of the PrP Gene. Ablation of the $\operatorname{PrP}$ gene in Tg $\left(\right.$ Prn- $\left.\mathrm{P}^{0 / 0}\right)$ mice has, unexpectedly, not affected the development of these animals ${ }^{115)}$. In fact, they are healthy at almost 2 years of age. Prn- $\mathrm{P}^{0 / 0}$ mice are resistant to prions (Figure 7) and do not propagate scrapie infectivity ${ }^{8,9)}$.

Prn- $\mathrm{P}^{0 / 0}$ mice crossed with $\mathrm{Tg}(\mathrm{SHaPrP})$ mice were rendered susceptible to $\mathrm{SHa}$ prions but remained resistant to Mo prions ${ }^{8,9)}$. Since the absence of $\operatorname{PrP}^{\mathrm{c}}$ expression does not provoke disease, it is likely that scrapie and other prion diseases are a consequence of $\mathrm{PrP}^{\mathrm{sc}}$ accumulation rather than an inhibition of $\operatorname{PrP}^{\mathrm{C}}$ function ${ }^{115)}$.
} 

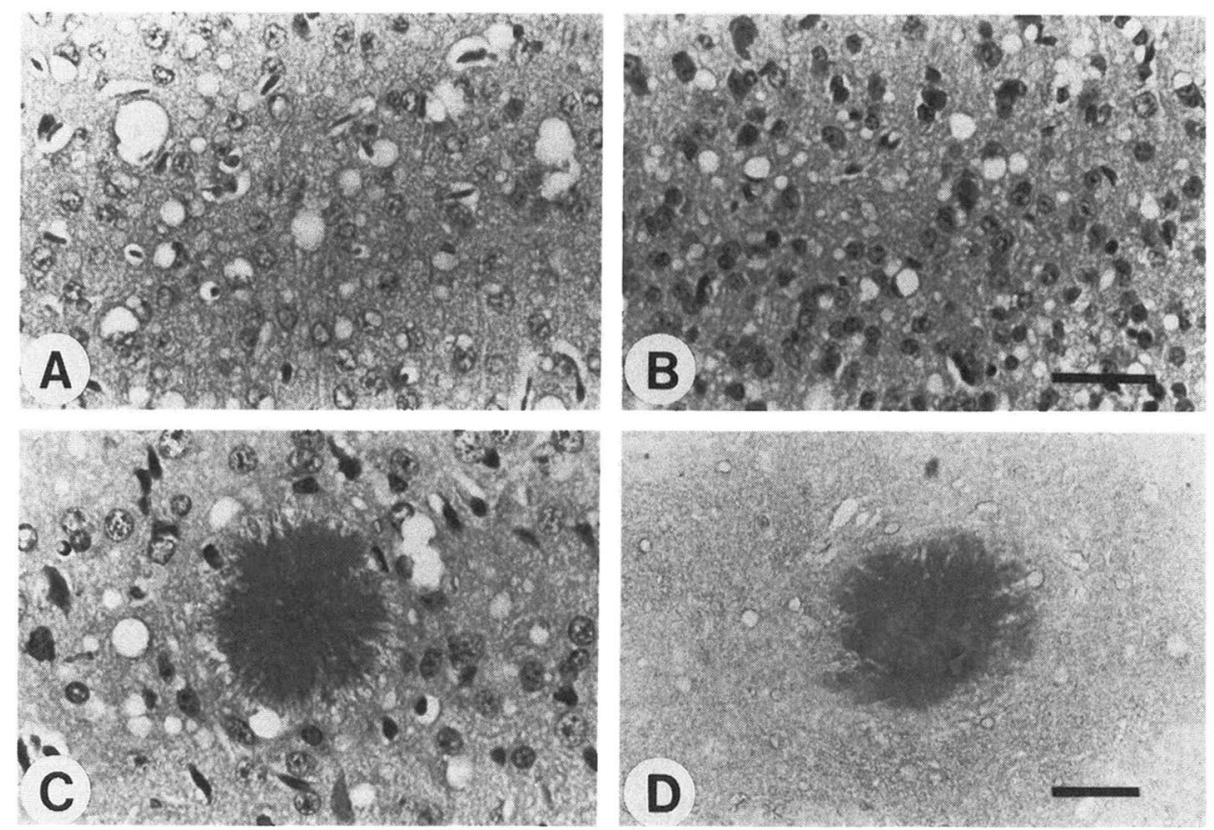

FIGURE 8

Neuropathology of $\mathrm{Tg}$ (MoPrP-P101L) mice developing neurodegeneration spontaneously. (A) Vacuolation in cerebral cortex of a Swiss CD-1 mouse that exhibited signs of neurologic dysfunction at 138 days after intracerebral inoculation with $\sim 10^{6} \mathrm{ID}_{50}$ units of RML scrapie prions. (B) Vacuolation in cerebral cortex of a $\mathrm{Tg}$ (MoPrP-P101L) mouse that exhibited signs of neurologic dysfunction at 252 days of age. (C) Kuru-type PrP amyloid plaque stained with periodic acid Schiff in the caudate nucleus of a Tg (MoPrP.P101L) mouse that exhibited signs of neurologic dysfunction. (D) PrP amyloid plaques stained with $\alpha$-PrP antiserum (RO73) in the caudate nucleus of a Tg (MoPrP-P101L) mouse that exhibited signs of neurologic dysfunction. Bar in $\mathrm{B}$ also applies to $\mathrm{A}=50 \mu \mathrm{m}$. Bar in D also applies to $\mathrm{C}=25 \mu \mathrm{m}$. Reprinted from ${ }^{221}$.

Mice heterozygous (Prn- $\mathrm{P}^{0 /+}$ ) for ablation of the PrP gene had prolonged incubation times when inoculated with Mo prions (Figure 7$)^{9)}$. The Prn $\sim \mathrm{p}^{0 /+}$ mice developed signs of neurologic dysfunction at 400-460 days after inoculation. These findings are in accord with studies on $\mathrm{Tg}$ ( $\mathrm{SHaPrP}$ ) mice in which increased $\mathrm{SHaPrP}$ expression was accompanied by diminished incubation times (Figure $5 \mathrm{~B})^{39)}$.

Since Prn- $\mathrm{P}^{0 / 0}$ mice do not express $\mathrm{PrP}^{\mathrm{c}}$, we reasoned that they might more readily produce $\alpha$-PrP antibodies. Prn- $\mathrm{P}^{0 / 0}$ mice immunized with Mo or SHa prion rods produced $\alpha$-PrP antisera which bound $\mathrm{Mo}$, SHa and $\mathrm{Hu} \operatorname{PrP}{ }^{9}$. These findings contrast with earlier studies in which $\alpha$-MoPrP antibodies could not be produced in mice presum- ably because the mice had been rendered tolerant by the presence of $\mathrm{MoPr} \mathrm{P}^{\mathrm{c}}{ }^{116-118)}$. That Prn- $\mathrm{P}^{0 / 0}$ mice readily produce $\alpha$-PrP antibodies is consistent with the hypothesis that the lack of an immune response in prion diseases is due to the fact that $\mathrm{PrP}^{\mathrm{c}}$ and $\mathrm{PrP}^{\mathrm{Sc}}$ share many epitopes. Whether Prn- $\mathrm{P}^{0 / 0}$ mice produce $\alpha$-PrP antibodies that specifically recognize conformational dependent epitopes present on $\mathrm{PrP}^{\mathrm{sc}}$ but absent from $\mathrm{PrP}^{\mathrm{c}}$ remains to be determined.

Modeling of GSS in Tg (MoPrP-P101L) Mice. The condon 102 point mutation found in GSS patients was introduced into the MoPrP gene and $\mathrm{Tg}$ (MoPrP-P101L) H mice were created expressing high $(\mathrm{H})$ levels of the mutant transgene product. 
The two lines of $\mathrm{Tg}$ (MoPrP-P101L) $\mathrm{H}$ mice designated 174 and 87 spontaneously developed CNS degeneration, characterized by clinical signs indistinguishable from experimental murine scrapie and neuropathology consisting of widespread spongiform morphology and astrocytic gliosis ${ }^{36)}$ and $\operatorname{PrP}$ amyloid plaques (Figure $8{ }^{37}{ }^{37}$. By inference, these results contend that $\mathrm{PrP}$ gene mutations cause GSS, familial CJD and FFI.

Brain extracts prepared from spontaneously ill $\mathrm{Tg}$ (MoPrP-P101L) H mice transmitted CNS degeneration to Tg196 mice expressing low levels of the mutant transgene product and some Syrian hamsters ${ }^{37)}$. Many Tg196 mice and some Syrian hamsters developed CNS degeneration between 200 and 700 days after inoculation, while inoculated CD-1 Swiss mice remained well. Serial transmission of CNS degeneration in Tg196 mice required about one year while serial transmission in Syrian hamsters occurred after $\sim 75 \mathrm{~d}^{37}$. Although brain extracts prepared from Tg (MoPrP-P101L) H mice transmitted CNS degeneration to some inoculated recipients, little or no $\mathrm{PrP}^{\mathrm{sc}}$ was detected by immunoassays after limited proteolysis. Undetectable or low levels of $\mathrm{PrP}^{\mathrm{Sc}}$ in the brains of these Tg (MoPrP-P101L) $\mathrm{H}$ mice are consistent with the results of these transmission experiments which suggest low titers of infectious prions. Though no $\mathrm{PrP}^{\mathrm{sc}}$ was detected in the brains of inoculated Tg196 mice exhibiting neurologic dysfunction by immunoassays after limited proteolysis, $\operatorname{PrP}$ amyloid plaques as well as spongiform degeneration were frequently found. The neurodegeneration found in inoculated $\mathrm{Tg} 196$ mice seems likely to result from a modification of mutant $\operatorname{PrP}^{\mathrm{c}}$ that is initiated by mutant $\mathrm{PrP}^{\mathrm{sc}}$ present in the brain extracts prepared from ill $\mathrm{Tg}$ (MoPrP-P101L) H mice. In support of this explanation are the findings in some of the inherited human prion diseases as described above where neither protease-resistant $\operatorname{PrP}{ }^{119,120)}$ nor transmission to experimental rodents could be demonstrated ${ }^{22}$. Furthermore, transmission of disease from $\mathrm{Tg}$ (MoPrP-P101L) H mice to Tg196 mice but not to Swiss mice is consistent with earlier findings which demonstrate that homotypic interactions between
$\operatorname{PrP}^{c}$ and $\operatorname{PrP}^{s c}$ feature in the formation of $\mathrm{PrP}^{\mathrm{sc}}$.

In other studies, modifying the expression of mutant and wt PrP genes in Tg mice permitted experimental manipulation of the pathogenesis of both inherited and infectious prion diseases. Although overexpression of the wtPrP-A transgene $\sim 8$-fold was not deleterious to the mice, it did shorten scrapie incubation times from $\sim 145 \mathrm{~d}$ to $\sim 45$ d after inoculation with Mo scrapie prions (Glenn C. Telling, Takeshi Haga, Dallas Foster, Shu-Lian Yang, Stephen J. DeArmond and Stanley B. Prusiner, in preparation). In contrast, overexpression at the same level of a PrP-A transgene mutated at codon 101 produced spontaneous, fatal neurodegeneration between 150 and $300 \mathrm{~d}$ of age in two new lines of Tg (MoPrP-P101L) mice designated 2866 and 2247. Genetic crosses of Tg (MoPrP-P101 L) 2866 mice with gene targeted mice lacking both PrP alleles (Prn- $\mathrm{P}^{0 / 0}$ ) produced animals with a highly synchronous onset of illness between 150 and 160 days of age. The Tg (MoPrP-P101L) 2866/Prn-P $\mathrm{P}^{0 / 0}$ mice had numerous PrP plaques and widespread spongiform degeneration in contrast to the Tg2866 and 2247 mice that exhibited spongiform degeneration but only a few PrP amyloid plaques. Another line of mice designated $\mathrm{Tg} 2862$ overexpress the mutant transgene $\sim 32$-fold and develop fatal neurodegeneration between 200 and $400 \mathrm{~d}$ of age. $\mathrm{Tg}$ 2862 mice exhibited the most severe spongiform degeneration and had numerous, large PrP amyloid plaques. While mutant $\operatorname{PrP}^{\mathrm{c}}(\mathrm{P} 101 \mathrm{~L})$ clearly produces neurodegeneration, wtPrP $\mathrm{P}^{\mathrm{c}}$ profoundly modifies both the age of onset of illness and the neuropathology for a given level of transgene expression. These findings and those from other studies ${ }^{38)}$ suggest that mutant and wtPrP interact, perhaps through a chaperone-like protein, to modify the pathogenesis of the dominantly inherited prion diseases.

\section{PROTEINS MODIFYING PRION DISEASES THAT ARE NOT ENCODED BY PrP GENES}

While the results of the foregoing investigations indicate that $\operatorname{PrP}$ transgenes modulate virtually all aspects of scrapie, including prion propagation, 
incubation time length, synthesis of $\mathrm{PrP}^{\mathrm{sc}}$, the species barrier and neuropathologic lesions, evidence for the role of proteins not encoded by PrP genes is beginning to emerge. In particular, studies with $\mathrm{Tg}(\mathrm{MHu} 2 \mathrm{M})$ and $\mathrm{Tg}(\mathrm{HuPrP})$ mice argue for the existencce of a species-specific factor as noted above that has provisionally been designated protein $\mathrm{X}^{38)}$. Investigations of prion strains in congenic mice suggest that a gene linked to but separate from PrP profoundly modifies the neuropathology of scrapie ${ }^{121}$. We have provisionally designated this gene product as protein $\mathrm{Y}$.

\section{Protein $X$ and the Transmission of Prions.}

Attempts to abrogate the prion species barrier between humans and mice by using an approach similar to that described for the abrogation of the species barrier between Syrian hamsters and mice were unsuccessful. Mice expressing $\mathrm{HuPrP}$ transgenes did not develop signs of CNS dysfuction more rapidly or frequently than non- $\mathrm{Tg}$ controls ${ }^{38}$.

The successful breaking of the species barrier between humans and mice has its origins in a set of studies with Tg mice expressing chimeric PrP genes derived from SHa and Mo PrP genes ${ }^{122)}$. One SHa/. MoPrP gene, designated MH2M PrP, contains five amino acid substitutions encoded by $\mathrm{SHaPrP}$, while another construct designated MHM2 PrP has two substitutions. Tg ( $\mathrm{MH} 2 \mathrm{M} \mathrm{PrP}$ ) mice were susceptible to both SHa or Mo prions, whereas three lines expressing MHM2 PrP were resistant to SHa prions 40). The brains of $\mathrm{Tg}$ (MH2M PrP) mice dying of scrapie contained chimeric $\operatorname{PrP}^{\mathrm{sc}}$ and prions with an artificial host range favoring propagation in mice that express the corresponding chimeric PrP, and were also transmissible, at reduced efficiency, to non- $\mathrm{Tg}$ mice and hamsters. These findings provided additional genetic evidence for homophilic interactions between $\mathrm{PrP}^{\mathrm{sc}}$ in the inoculum and $\mathrm{PrP}^{\mathrm{c}}$ synthesized by the host.

With the recognition that $\mathrm{Tg}(\mathrm{HuPrP})$ mice were not suitable recipients for the transmission of $\mathrm{Hu}$ prions, we constructed $\mathrm{Tg}(\mathrm{MHu} 2 \mathrm{M})$ mice analogous to the Tg (MH2M) mice described above. Human PrP differs from mouse PrP at 28 of 254 positions
102) while chimeric MHu2MPrP differs at 9 residues. The mice expressing the MHu2M transgene are susceptible to human prions and exhibit abbreviated incubation times of $\sim 200$ days ${ }^{38}$. In these initial studies the chimeric MHu2M transgene encoded a Met at codon 129 and all three of the patients were homozygous for Met at this residue. Two of the cases were sporadic CJD and the third was an iatrogenic case which occurred after treatment with pituitary derived human growth hormone (HGH). Whether it will be necessary to match the $\operatorname{PrP}$ genotype of the $\mathrm{Tg}(\mathrm{MHu} 2 \mathrm{M})$ mouse with that of the CJD patient from whom the inoculum was derived, or some variations in sequence can be tolerated, remains to be established.

From $\mathrm{Tg}(\mathrm{SHaPrP})$ mouse studies, prion propagation is thought to involve the formation of a complex between $\operatorname{PrP}^{\mathrm{sc}}$ and the homotypic substrate $\operatorname{PrP}^{c}{ }^{39)}$. Attempts to mix $\operatorname{PrP}^{\mathrm{sc}}$ with $\operatorname{PrP}^{\mathrm{c}}$ have failed to produce nascent $\operatorname{Pr} P^{s c}{ }^{87}$, raising the possibility that proteins such as chaperones might be involved in catalyzing the conformational changes that feature in the formation of $\mathrm{PrP}^{\mathrm{sc}}{ }^{48)}$. One explanation for the difference in susceptibility of $\mathrm{Tg}$ (MHu2M) and $\mathrm{Tg}(\mathrm{HuPrP})$ mice to Hu prions in mice may be that mouse chaperones catalyzing the refolding of $\mathrm{PrP}^{\mathrm{c}}$ into $\mathrm{PrP}^{\mathrm{sc}}$ can readily interact with the MHu2MPrPc/HuPrPc ${ }^{\text {sD }}$ complex but not with $\mathrm{HuPrP} / \mathrm{HuPrP} \mathrm{P}^{\mathrm{CJD}}$. The identification of protein $\mathrm{X}$ is an important avenue of research since isolation of this protein or complex of proteins would presumably facilitate studies of $\mathrm{PrP}^{\mathrm{sc}}$ formation. To date, attempts to isolate specific proteins that bind to $\operatorname{PrP}$ have been disappointing ${ }^{123)}$. Whether or not identification of protein $\mathrm{X}$ will require isolation of a ternary complex composed of $\operatorname{PrP}^{\mathrm{c}}, \mathrm{PrP}^{\mathrm{sc}}$ and protein $\mathrm{X}$ remains to be determined.

The sensitivity of $\mathrm{Tg}(\mathrm{MHu} 2 \mathrm{M})$ mice to $\mathrm{Hu}$ prions suggests that a similar approach to the construction of $\mathrm{Tg}$ mice susceptible to bovine spongiform encephalopathy (BSE) and scrapie sheep prions may prove fruitful. The BSE epidemic has led to considerable concern about the safety for humans consuming beef and dairy products. Although epidemiologic studies over the past two 
decades argue that humans do not contract CJD from scrapie-infected sheep products ${ }^{24-26)}$, it is unknown whether any of the seven amino acid substitutions that distinguish bovine from sheep $\operatorname{PrP}$ render bovine prions permissive in humans ${ }^{113}$. Whether $\mathrm{Tg}$ (MHu2M) mice are susceptible to bovine or sheep prions is unknown.

\section{Protein $\mathrm{Y}$ and the Neuropathology of Prion}

Disease. Four lines of congenic mice were produced by crossing the $\operatorname{PrP}$ gene of the ILn/J mouse onto C57BL. The four lines of congenic mice are designated: B6.I-4 for B6.I-B2 $m^{\mathrm{a}}$, B6.I-1 for B6. I-Prn- $p^{\mathrm{b}}$, B6.I-2 for B6.I-II-1 $1 a^{\mathrm{d}} P r n-p^{\mathrm{b}}$, B6.I-3 for B6. I- $B 2 m^{\text {a }} P r n-p^{\text {b }}{ }^{124)}$. Neuropathologic examination of B6.I-1, B6.I-2, I/LnJ and VM/Dk mice inoculated with $87 \mathrm{~V}$ prions showed numerous $\operatorname{PrP}$ amyloid plaques in accord with an earlier report on $\mathrm{VM} / \mathrm{Dk}$ mice ${ }^{125)}$. In B6. I-1 mice intense spongiform degeneration, gliosis, and PrP immunostaining were found in the ventral posterior lateral (VPL) nucleus of the thalamus, the habenula and the raphe nuclei of the brainstem ${ }^{1211}$. These same regions showed intense immunoreactivity for $\mathrm{PrP}^{\mathrm{sc}}$ on histoblots. Unexpectedly, B6.I-2 and ILn/J mice exhibited only mild vacuolation of the thalamus and brainstem. These findings suggest that a locus near Prn-p influences the deposition of $\mathrm{PrP}^{\mathrm{sc}}$, and thus vacuolation, in the thalamus, the habenula and raphe nuclei. We have provisionally designated the product of this gene protein $\mathrm{Y}$.

Identification of the gene that encodes protein $\mathrm{Y}$ that is distinct from but near Prn-p will be important. The gene Y product appears to control, at least in part, neuronal vacuolation and presumably $\mathrm{PrP}^{\mathrm{sc}}$ deposition in mice inoculated with scrapie prions. lsolation of protein $\mathrm{Y}$ should be helpful in dissecting the molecular events that feature in the pathogenesis of the prion diseases.

\section{PRION DIVERSITY}

\section{Prion Strains and Variations in Patterns of Dis-}

ease. For many years, studies of experimental scrapie were performed exclusively with sheep and goats. The disease was first transmitted by intraocular inoculation ${ }^{126)}$ and later by intracerebral, oral, subcutaneous, intramuscular and intravenous injections of brain extracts from sheep developing scrapie. Incubation periods of 1-3 years were common and often many of the inoculated animals failed to develop disease ${ }^{127-129)}$. Different breeds of sheep exhibited markedly different susceptibilities to scrapie prions inoculated subcutaneously, suggesting that the genetic background might influence host permissiveness ${ }^{130}$.

The diversity of scrapie prions was first appreciated in goats inoculated with "hyper" and "drowsy" isolates ${ }^{131)}$. Subsequently, studies in mice demonstrated the existence of many scrapie "strains" 132-135) which continues to pose a fascinating conundrum. What is the macromolecule that carries the information required for each strain to manifest a unique set of biological properties if it is not a nucleic acid?

There is good evidence for multiple "strains" or distinct isolates of prions as defined by specific incubation times, distribution of vacuolar lesions and patterns of $\mathrm{PrP}^{\mathrm{sc}}$ accumulation 136-139). The lengths of the incubation times have been used to distinguish prion strains inoculated into sheep, goats mice and hamsters. Dickinson and his colleagues developed a system for "strain typing" by which mice with genetically determined short and long incubation times were used in combination with the F1 cross ${ }^{136,140,141)}$. For example, C57BL mice exhibited short incubation times of $\sim 150$ days when inoculated with either the $\mathrm{Me} 7$ or Chandler isolates ; VM mice inoculated with these same isolates had prolonged incubation times of $\sim 300$ days. The mouse gene controlling incubation times was labeled Sinc and long incubation times were said to be a dominant trait because of prolonged incubation times in F1 mice. Prion strains were categorized into two groups based upon their incubation times:

(1) those causing disease more rapidly in "short" incubation time C57BL mice and (2) those causing disease more rapidly in "long" incubation time VM mice.

PrP Gene Dosage Controls the Length of the 
Table 4. MoPrP-A expression is a major determinant of incubation times in mice inoculated with the RML scrapie prions

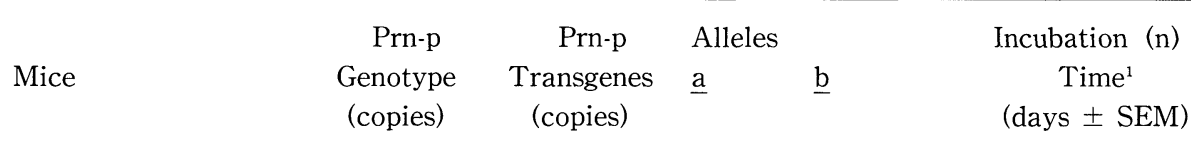

\begin{tabular}{|c|c|c|c|c|c|c|}
\hline Prn-P $\mathrm{P}^{0 / 0}$ & $0 / 0$ & & 0 & 0 & $>600$ & 4 \\
\hline Prn $-\mathrm{P}^{+10}$ & $a / 0$ & & 1 & 0 & $426 \pm 18$ & $9^{1}$ \\
\hline B6.I-1 & $\mathrm{b} / \mathrm{b}$ & & 0 & 2 & $360 \pm 16$ & $7^{2}$ \\
\hline B6.I-2 & $\mathrm{b} / \mathrm{b}$ & & 0 & 2 & $379 \pm 8$ & $10^{2}$ \\
\hline B6.I-3 & $\mathrm{b} / \mathrm{b}$ & & 0 & 2 & $404 \pm 10$ & 20 \\
\hline$(\mathrm{B} 6 \times \mathrm{B} 6 . \mathrm{I}-1) \mathrm{F} 1$ & $\mathrm{a} / \mathrm{b}$ & & 1 & 1 & $268 \pm 4$ & 7 \\
\hline B6.I-1 $\times$ Tg $\left(\mathrm{MoPrP}-\mathrm{B}^{0 / 0}\right) 15$ & $\mathrm{a} / \mathrm{b}$ & & 1 & 1 & $255 \pm 7$ & $11^{3}$ \\
\hline B6.I-1 $\times$ Tg $\left(\right.$ MoPrP-B $\left.-B^{0 / 0}\right) 15$ & $\mathrm{a} / \mathrm{b}$ & & 1 & 1 & $274 \pm 3$ & $9^{4}$ \\
\hline B6.I-1 $\times$ Tg $\left(\mathrm{MoPrP}^{\left.-\mathrm{B}^{+/ 0}\right)} 15\right.$ & $a / b$ & $\mathrm{bbb} / 0$ & 1 & 4 & $166 \pm 2$ & $11^{3}$ \\
\hline B6.I-1 $\times$ Tg $\left(M o P r P-B^{+/ 0}\right) 15$ & $a / b$ & $\mathrm{bbb} / 0$ & 1 & 4 & $162 \pm 3$ & $8^{4}$ \\
\hline C57BL/6J (B6) & $\mathrm{a} / \mathrm{a}$ & & 2 & 0 & $143 \pm 4$ & 8 \\
\hline B6.I-4 & $\mathrm{a} / \mathrm{a}$ & & 2 & 0 & $144 \pm 5$ & 8 \\
\hline non-Tg (MoPrP-B $\left.\mathrm{B}^{0 / 0}\right) 15$ & $a / a$ & & 2 & 0 & $130 \pm 3$ & 10 \\
\hline Tg $\left(\mathrm{MoPrP}-\mathrm{B}^{+/ 0}\right) 15$ & $a / a$ & $\mathrm{bbb} / 0$ & 2 & 3 & $115 \pm 2$ & 18 \\
\hline $\operatorname{Tg}\left(\mathrm{MoPrP}-\mathrm{B}^{+/+}\right) 15$ & $a / a$ & $\mathrm{bbb} / \mathrm{bbb}$ & 2 & 6 & $111 \pm 5$ & 5 \\
\hline $\mathrm{Tg}\left(\mathrm{MoPrP}-\mathrm{B}^{+/ 0}\right) 94$ & $a / a$ & $>30 \mathrm{~b}$ & 2 & $>30$ & $75 \pm 2$ & $15^{5}$ \\
\hline Tg $\left(\right.$ MoPrP-A $\left.A^{+/ 0}\right)$ B4053 & $a / a$ & $>30 \mathrm{a}$ & $>30$ & 0 & $50 \pm$ & 16 \\
\hline
\end{tabular}

a Data from ref ${ }^{9}$.

b Data from ref ${ }^{124}$.

c The homozygous $\mathrm{Tg}\left(\mathrm{MoPrP}-\mathrm{B}^{+/+}\right) 15$ mice were maintained as a distinct subline selected for transgene homozygosity two generations removed from the $(\mathrm{B} 6 \times \mathrm{LT} / \mathrm{Sv}) \mathrm{F} 2$ founder.

Hemizygous Tg $\left(\mathrm{MoPrP}-\mathrm{B}^{+/ 0}\right) 15$ mice were produced by crossing the Tg (MoPrP-B $\left.\mathrm{B}^{+/+}\right) 15$ line with $\mathrm{B} 6$ mice.

d $\mathrm{Tg}\left(\mathrm{MoPrP}-\mathrm{B}^{+/ 0}\right) 15$ mice were maintained by repeated backcrossing to $\mathrm{B} 6$ mice.

e Data from 149 .

Scrapie Incubation Time. More than a decade of study was required to unravel the mechanism responsible for the "dominance" of long incubation times; not unexpectedly, long incubation times were found not to be dominant traits. Instead, the apparent dominance of long incubation times is due to a gene dosage effect ${ }^{121)}$.

Our own studies began with the identification of a widely available mouse strain with long incubation times. ILn/J mice inoculated with RML prions were found to have incubation times exceeding 200 days ${ }^{142)}$, a finding that was confirmed by others ${ }^{143)}$. Once molecular clones of the PrP gene were available, we asked whether or not the PrP genes of short and long mice segregate with incubation times. A restriction fragment length polymorphism
(RFLP) of the PrP gene was used to follow the segregation of MoPrP genes (Prn- $p$ ) from short $\mathrm{NZW}$ or C57BL mice with long ILn/J mice in F1 and F2 crosses. This approach permitted the demonstration of genetic linkage between a Prn-p and a gene modulating incubation times $(P r n-i){ }^{144)}$. Other investigators have confirmed the genetic linkage, and one group has shown that the incubation time gene Sinc is also linked to $\operatorname{PrP}{ }^{145,146)}$. It now seems likely that the genes for PrP, Prn-i and Sinc are all congruent; the term Sinc is no longer used ${ }^{147)}$. The $\mathrm{PrP}$ sequences of NZW with short and long scrapie incubation times, respectively, differ at codons $108(\mathrm{~L} \rightarrow \mathrm{F})$ and $189(\mathrm{~T} \rightarrow \mathrm{V}){ }^{148}$.

Although the amino acid substitutions in $\operatorname{PrP}$ that distinguish Prn-P $P^{\mathrm{a}}$ from Prn- $p^{\mathrm{b}}$ mice argued for the 
Table 5. Mismatching of $\operatorname{Pr} P$ allotypes between $\mathrm{PrP}^{\mathrm{sc}}$ in the inoculum and $\operatorname{PrP}^{\mathrm{c}}$ in the inoculated host extends prion incubation times in congenic mice

\begin{tabular}{|c|c|c|c|c|c|}
\hline \multirow{2}{*}{ Mice } & \multicolumn{2}{|c|}{ Host } & \multirow{2}{*}{$\begin{array}{l}\text { Inoculum } \\
\text { Genotype }\end{array}$} & \multicolumn{2}{|l|}{ Donor } \\
\hline & Genotype & Donor & & Incubation Time & (n) \\
\hline$\overline{\mathrm{C} 57 \mathrm{BL} / 6 \mathrm{~J} \quad(\mathrm{~B} 6)}$ & $a / a$ & CD-1 & $\mathrm{a} / \mathrm{a}$ & $143 \pm 4$ & $(8)$ \\
\hline B6.I-4 & $a / a$ & $\mathrm{NZW}$ & $a / a$ & $144 \pm 5$ & $(8)$ \\
\hline B6.I-4 & $\mathrm{a} / \mathrm{a}$ & $\mathrm{I} / \mathrm{Ln}$ & $\mathrm{b} / \mathrm{b}$ & $150 \pm 6$ & $(6)$ \\
\hline B6.I-2 & $\mathrm{b} / \mathrm{b}$ & CD-1 & $a / a$ & $360 \pm 16$ & (8) \\
\hline B6.I-2 & $\mathrm{b} / \mathrm{b}$ & NZW & $a / a$ & $404 \pm 4$ & (20). \\
\hline B6.I-2 & $\mathrm{b} / \mathrm{b}$ & $\mathrm{I} / \mathrm{Ln}$ & $\mathrm{b} / \mathrm{b}$ & $237 \pm 8$ & (17) \\
\hline $\mathrm{I} / \mathrm{LnJ} \mathrm{J}^{\mathrm{a}}$ & $\mathrm{b} / \mathrm{b}$ & CD-1 & $\mathrm{a} / \mathrm{a}$ & $314 \pm 13$ & (11) \\
\hline $\mathrm{I} / \mathrm{LnJ}$ & $\mathrm{b} / \mathrm{b}$ & NZW & $a / a$ & $283 \pm 21$ & (8) \\
\hline $\mathrm{I} / \mathrm{LnJ}$ & $\mathrm{b} / \mathrm{b}$ & $\mathrm{I} / \mathrm{Ln}$ & $\mathrm{b} / \mathrm{b}$ & $193 \pm 6$ & (16) \\
\hline
\end{tabular}

a $\mathrm{I} / \mathrm{LnJ}$ results previously reported ${ }^{121}$.

congruency of Prn-p and Prn-i, experiments with $P r n-p^{\mathrm{a}}$ mice expressing Prn- $p^{\mathrm{b}}$ transgenes demonstrated a "paradoxical" shortening of incubation times ${ }^{149)}$. We had predicted that these Tg mice would exhibit a prolongation of the incubation time after inoculation with RML prions based on (Prn$p^{\mathrm{a}} \times$ Prn- $\left.p^{\mathrm{b}}\right)$ F1 mice which do exhibit long incubation times. We described those findings as "paradoxical shortening" because we and others had believed for many years that long incubation times are dominant traits ${ }^{136,144)}$. From studies of congenic and transgenic mice expressing different numbers of the $a$ and $b$ alleles of Prn-p (Table 4), we now realize that these findings were not paradoxical; indeed, they result from increased PrP gene dosage ${ }^{121)}$. When the RML isolate was inoculated into congenic and transgenic mice, increasing the number of copies of the a allele was found to be the major determinant in reducing the incubation time; however, increasing the number of copies of the $b$ allele also reduced the incubation time, but not to the same extent as that seen with the a allele (Table 4).

The discovery that incubation times are controlled by the relative dosage of $P m-p^{\mathrm{a}}$ and Prn- $p^{\mathrm{b}}$ alleles was foreshadowed by studies of $\mathrm{Tg}$

$(\mathrm{SHaPrP})$ mice in which the length of the incubation time after inoculation with $\mathrm{SHa}$ prions was inversely proportional to the transgene product,
$\mathrm{SHaPrP}^{\mathrm{c}}{ }^{39)}$. Not only does the $\operatorname{PrP}$ gene dose determine the length of the incubation time, but also the passage history of the inoculum, particularly in Prn $-p^{\mathrm{b}}$ mice (Table 5). The $\operatorname{PrP}^{\mathrm{sc}}$ allotype in the inoculum produced the shortest incubation times when it was the same as that of $\operatorname{PrP}^{\mathrm{C}}$ in the host ${ }^{150}$. The term "allotype" is used to describe allelic variants of PrP. To address the issue of whether gene products other than $\operatorname{PrP}$ might be responsible for these findings, we inoculated B6 and B6.I-4 mice carrying Prn- $\mathrm{p}^{\mathrm{a} / \mathrm{a}}$ as well as I/Ln, and B6.I-2 mice ${ }^{121,124)}$, with RML prions passaged in mice homozygous for either the a or b allele of Prn-p (Table 5). CD-1 and NZW/LacJ mice produce prions containing $\mathrm{PrP}^{\mathrm{sc}}$-A encoded by $P r n-p^{\mathrm{a}}$ while I/LnJ mice produce $\mathrm{PrP}^{\mathrm{sc}}$ - B prions. The incubation times in the congenic mice reflected the $\operatorname{PrP}$ allotype, rather than other factors acquired during prion passage. The effect of the allotype barrier was small when measured in Prn- $\mathrm{p}^{\mathrm{a} / \mathrm{a}}$ mice but was clearly demonstrable in Prn- $p^{\mathrm{b} / \mathrm{b}}$ mice. B6.I-2 congenic mice inoculated with prions from I/Ln mice had an incubation time of $237 \pm 8$ days compared to times of $360 \pm 16$ days and $404 \pm 4$ days for mice inoculated with prions passaged in CD-1 and NZW mice, respectively. Thus, previous passage of prions in Prn- $p^{\mathrm{b}}$ mice shortened the incubation time by $\sim 40$ \% when assayed in Prn- $p^{\mathrm{b}}$ mice, compared to those inoculated with prions passaged in $P r n-p^{\text {a }}$ mice ${ }^{150)}$. 
Table 6. MoPrPc $-\mathrm{A}$ inhibits the synthesis of $22 \mathrm{~A}$ scrapie prions

\begin{tabular}{|c|c|c|c|c|c|c|}
\hline Mice & $\begin{array}{c}\text { Prn-p } \\
\text { Genotype }\end{array}$ & $\begin{array}{c}\text { Prn-p } \\
\text { Transgenes } \\
\text { (copies) }\end{array}$ & $\begin{array}{l}\text { Alleles } \\
\underline{\mathrm{a}}_{\text {(copies) }}\end{array}$ & $\underline{b}$ & $\begin{array}{c}\text { Incubation } \\
\text { Time } \\
\text { (days } \pm \text { SEM) }\end{array}$ & (n) \\
\hline B6.I-1 & $\mathrm{b} / \mathrm{b}$ & & 0 & 2 & $194 \pm 10$ & 7 \\
\hline$(\mathrm{B} 6 \times \mathrm{B} 6 . \mathrm{I}-1) \mathrm{F} 1$ & $a / b$ & & 1 & 1 & $508 \pm 14$ & 7 \\
\hline $\mathrm{C} 57 \mathrm{BL} / 6 \mathrm{~J} \quad(\mathrm{~B} 6)$ & $\mathrm{a} / \mathrm{a}$ & & 2 & 0 & $405 \pm 2$ & 8 \\
\hline non-Tg (MoPrP-B B $\left.^{0 / 0}\right) 15$ & $\mathrm{a} / \mathrm{a}$ & & 2 & 0 & $378 \pm 8$ & $3^{\mathrm{a}}$ \\
\hline Tg $\left(\mathrm{MoPrP}-\mathrm{B}^{+/ 0}\right) 15$ & $\mathrm{a} / \mathrm{a}$ & $\mathrm{bbb} / 0$ & 2 & 3 & $318 \pm 14$ & $15^{\mathrm{a}}$ \\
\hline Tg $\left(\right.$ MoPrP-B $\left.{ }^{+/ 0}\right) 15$ & $\mathrm{a} / \mathrm{a}$ & $\mathrm{bbb} / 0$ & 2 & 3 & $395 \pm 12$ & $6^{\mathrm{b}}$ \\
\hline Tg $\left(\mathrm{MoPrP}-\mathrm{B}^{+/+}\right) 15$ & $\mathrm{a} / \mathrm{a}$ & $\mathrm{bbb} / \mathrm{bbb}$ & 2 & 6 & $266 \pm 1$ & $6^{\mathrm{a}}$ \\
\hline $\operatorname{Tg}\left(\mathrm{MoPrP}-\mathrm{B}^{+/+}\right) 15$ & $\mathrm{a} / \mathrm{a}$ & $\mathrm{bbb} / \mathrm{bbb}$ & 2 & 6 & $286 \pm 15$ & $5^{\mathrm{b}}$ \\
\hline
\end{tabular}

a The homozygous Tg $\left(\mathrm{MoPrP}-\mathrm{B}^{+/+}\right) 15$ mice were maintained as a distinct subline selected for transgene homozygosity two generations removed from the $(\mathrm{B} 6 \times \mathrm{LT} / \mathrm{Sv}) \mathrm{F} 2$ founder.

Hemizygous Tg (MoPrP-B $\left.\mathrm{B}^{+/ 0}\right) 15$ mice were produced by crossing the Tg (MoPrP-B $\left.{ }^{+/+}\right) 15$ line with $\mathrm{B} 6$ mice.

b $\mathrm{Tg}\left(\mathrm{MoPrP}-\mathrm{B}^{+/ 0}\right) 15$ mice were maintained by repeated backcrossing to $\mathrm{B} 6$ mice.

Overdominance. The phenomenon of "overdominance" in which incubation times in F1 hybrids are longer than those of either parent ${ }^{151)}$ contributed to the confusion surrounding control of scrapie incubation times. When the $22 \mathrm{~A}$ scrapie isolate was inoculated into B6, B6.I-1 and $(\mathrm{B} 6 \times \mathrm{B} 6 . \mathrm{I}-1) \mathrm{F} 1$, overdominance was observed: the scrapie incubation time in B6 mice was $405 \pm 2$ days, in B6. I mice $194 \pm 10$ days and in $(\mathrm{B} 6 \times$ B6.I-1) F1 mice $508 \pm$ 14 days (Table 6). Shorter incubation times were observed in $\mathrm{Tg}$ (MoPrP-B) 15 mice which were either homozygous or hemizygous for the Prn- $p^{\mathrm{b}}$ transgene. Hemizygous $\mathrm{Tg}\left(\mathrm{MoPrP}-\mathrm{B}^{+10}\right) 15$ mice exhibited a scrapie incubation time of $395 \pm 12$ days while the homozygous mice had an incubation time of $286 \pm 15$ days.

As with the results with the RML isolate (Table $5)$, the findings with the $22 \mathrm{~A}$ isolate can be explained on the basis of gene dosage; however, the relative effects of the $\mathrm{a}$ and $\mathrm{b}$ alleles differ in two respects. First, the $\mathrm{b}$ allels is the major determinant of the scrapie incubation time with the $22 \mathrm{~A}$ isolate, not the a allele. Second, increasing the number of copies of the a allele does not diminish the incubation but prolongs it: the a allele is inhibitory with the $22 \mathrm{~A}$ isolate (Table 6 ). With the $87 \mathrm{~V}$ prion isolate the inhibitory effect of the Prn- $p^{\text {a }}$ allele is even more pronounced since only a few $P r n-p^{\mathrm{a}}$ and $\left(P r n-p^{\mathrm{a}} \times\right.$ Prn- $\left.p^{\text {b }}\right)$ F1 mice develop scrapie after $>600$ days post-inoculation ${ }^{121)}$.

The most interesting feature of the incubation time profile for $22 \mathrm{~A}$ is the overdominance of the a allele of Prn- $p$ in prolonging incubation period. On the basis of overdominance, Dickinson and Outram put forth the replication site hypothesis postulating that dimers of the Sinc gene product feature is the replication of the scrapie agent ${ }^{152)}$. The results in Table 6 are compatible with the interpretation that the target for $\mathrm{PrP}^{\mathrm{sc}}$ may be a $\mathrm{PrP}^{\mathrm{c}}$ dimer or multimer. The assumptions under this model are that $\operatorname{PrP}^{\mathrm{C}}-\mathrm{B}$ dimers are more readily converted to $\mathrm{PrP}^{\mathrm{sc}}$ than are $\mathrm{PrP}^{\mathrm{c}}-\mathrm{A}$ dimers and that $\mathrm{PrP}^{\mathrm{c}}-\mathrm{A}$ : $\mathrm{PrP}^{\mathrm{c}}-\mathrm{B}$ heterodimers are even more resistant to conversion to $\operatorname{PrP}^{\mathrm{sc}}$ than $\mathrm{PrP}^{\mathrm{c}}$-A dimers. Increasing the ratio of PrP-B to PrP-A would lead to shorter incubation times by favoring the formation of $\mathrm{PrP}^{\mathrm{C}}$. B homodimers (Table 6). A similar mechanism may account for the relative paucity of individuals heterozygous for the Met/Val polymorphism at codon 129 of the humen $\operatorname{PrP}$ gene in spontaneous and iatrogenic $\mathrm{CJD}{ }^{98)}$. Altenatively, $\mathrm{PrP}^{\mathrm{C}}-\mathrm{PrP}^{\mathrm{sc}}$ interaction can be broken down to two distinct aspects: binding affinity and efficacy of conversion to $\mathrm{PrP}^{\mathrm{sc}}$. 
If PrP-A has a higher affinity for 22A $\operatorname{PrP}^{\mathrm{sc}}$ than does $\operatorname{PrP}^{\mathrm{c}}-\mathrm{B}$, but is inefficiently converted to $\operatorname{PrP}^{\mathrm{sc}}$, the exceptionally long incubation time of Prn- $\mathrm{p}^{\mathrm{a} / \mathrm{b}}$ heterozygotes might reflect reduction in the supply of $22 \mathrm{~A}$ prions available for interaction with the $\mathrm{PrP}^{\mathrm{C}}-\mathrm{B}$ product of the single Prn- $\mathrm{p}^{\mathrm{b}}$ allele. Additionally, $\operatorname{PrP}^{\mathrm{c}}-\mathrm{A}$ may inhibit the interaction of $22 \mathrm{~A}$ $\operatorname{PrP}^{\mathrm{sc}}$ with $\mathrm{PrP}^{\mathrm{c}}-\mathrm{B}$ leading to prolongation of the incubation time. This interpretation is supported by prolonged incubation times in $\mathrm{Tg}(\mathrm{SHaPrP})$ mice inoculated with mouse prions in which $\mathrm{SHaPrP}^{\mathrm{C}}$ is thought to inhibit the binding of $\mathrm{MoPrP}^{\mathrm{sc}}$ to the substrate $\mathrm{MoPrP}{ }^{\mathrm{C}}{ }^{39)}$.

Patterns of $\operatorname{PrP}^{\mathrm{sc}}$ Deposition. Besides measurements of the length of the incubation time, profiles of spongiform degeneration have also been used to characterize different prion strains ${ }^{137,153)}$. With the development of a new procedure for in situ detection of $\mathrm{PrP}^{\mathrm{Sc}}$, designated histoblotting ${ }^{154)}$, it became possible to localize and quantify $\mathrm{PrP}^{\mathrm{sc}}$ as well as to determine whether or not "strains" produce different, reproducible patterns of $\mathrm{PrP}^{\mathrm{sc}}$ accumulation 139,155).

Histoblotting overcame two obstacles that plagued $\mathrm{PrP}^{\mathrm{sc}}$ detection in brain by standard immunohistochemical techniques: the presence of $\operatorname{PrP}^{\mathrm{C}}$ and weak antigenicity of $\mathrm{PrP}^{\mathrm{sc}}{ }^{156)}$. The histoblot is made by pressing $10 \mu \mathrm{m}$ thick cryostat sections of fresh frozen brain tissue to nitrocellulose paper. To localize protease-resistant $\mathrm{PrP}^{\mathrm{sc}}$ in brain, the histoblot is digested with proteinase $\mathrm{K}$ to eliminate $\operatorname{PrP}^{\mathrm{c}}$, followed by denaturation of the undigested $\mathrm{PrP}^{\mathrm{Sc}}$ to enhance binding of $\mathrm{PrP}$ antibodies. Immunohistochemical staining yields a far more intense, specific and reproducible PrP signal than can be achieved by immunohistochemistry on standard tissue sections. The intensity of immunostaining correlates well with neurochemical estimates of $\mathrm{PrP}^{\mathrm{Sc}}$ concentration in homogenates of dissected brain regions. $\operatorname{PrP}^{\mathrm{C}}$ can be localized in histoblots of normal brains by eliminating the proteinase $\mathrm{K}$ digestion step.

Comparisons of $\mathrm{PrP}^{\mathrm{sc}}$ accumulation on histoblots with histologic sections showed that $\operatorname{PrP}^{\mathrm{sc}}$ deposi- tion preceded vacuolation and only those regions with $\mathrm{PrP}^{\mathrm{sc}}$ underwent degeneration. Microdissection of individual brain regions confirmed the conclusions of the histoblot studies : those regions with high levels of $\operatorname{PrP}$ 27-30 had intense vacuolation ${ }^{157}$. Thus, we concluded that the deposition of $\mathrm{PrP}^{\mathrm{sc}}$ is responsible for the neuropathologic changes found in the prion diseases.

While studies with both mice and Syrian hamsters established that each isolate has a specific signature as defined by a specific pattern of $\mathrm{PrP}^{\mathrm{sc}}$ accumulation in the brain ${ }^{121,139,155)}$, comparisons must be done on an isogenic background ${ }^{37,40)}$. Variations in the patterns of $\mathrm{PrP}^{\mathrm{sc}}$ accumulation were found to be equally as great as those seen between two strains when a single strain is inoculated in mice expressing different $\operatorname{PrP}$ genes. Based upon the initial studies which were performed in animals of a single genotype, we suggested that $\operatorname{PrP}^{\mathrm{sc}}$ synthesis occurs in specific populations of cells for a given distinct prion isolate.

\section{Are Prion Strains Different $\operatorname{PrP}^{\mathrm{sc}}$ Conformers ?}

Explaining the problem of multiple distinct prion isolates might be accommodated by multiple $\mathrm{PrP}^{\mathrm{sc}}$ conformers that act as templates for the folding of de novo synthesized $\mathrm{PrP}^{\mathrm{sc}}$ molecules during prion "replication" (Figure 4). Although it is clear that passage history can be responsible for the prolongation of incubation time when prions are passed between mice expressing different PrP allotypes ${ }^{150}$ or between species ${ }^{39}$, many scrapie strains show distinct incubation times in the same inbred host ${ }^{158)}$.

In recent studies we inoculated three strains of prions into congenic and $\mathrm{Tg}$ mice harboring various numbers of the a and $\mathrm{b}$ alleles of Prn- $p^{121)}$. The number of $P r n-p^{a}$ genes was the major determinant of incubation times in mice inoculated with the RML prion isolate and was inversely related to the length of the incubation time (Table 4). In contrast, the Prn- $p^{\text {a }}$ allele prevented scrapie in mice inoculated with $87 \mathrm{~V}$ prions. Prn- $p^{\mathrm{b}}$ genes were permissive for $87 \mathrm{~V}$ prions and shortened incubation times in most mice inoculated with $22 \mathrm{~A}$ prions (Table 6). Experiments with the $87 \mathrm{~V}$ isolate suggest that a 
genetic locus encoding protein $\mathrm{Y}$, distinct from Prn-p, controls the deposition of $\mathrm{PrP}^{\mathrm{sc}}$ and the attendant neuropathology. While each prion isolate produced distinguishable patterns of $\operatorname{PrP}^{\mathrm{sc}}$ accumulation in brain, a comparison of these patterns showed that those patterns found with RML and 22 A prions in congenic $P r n-p^{\mathrm{b}}$ mice were more similar than those with RML prions in Prn- a $^{\mathrm{a}}$ and Prn- $p^{\mathrm{b}}$ congenic mice. Thus, both the $\operatorname{PrP}$ genotype and prion isolate modify the distribution of $\mathrm{PrP}^{\mathrm{Sc}}$ and the length of the incubation time. These findings suggest that prion strain specified properties result from different affinities of $\mathrm{PrP}^{\mathrm{sc}}$ in the inocula for $\operatorname{PrP}^{\mathrm{c}}-\mathrm{A}$ and $\operatorname{PrP}^{\mathrm{c}}-\mathrm{B}$ allotypes encoded by the host.

Although the proposal for multiple $\mathrm{PrP}^{\mathrm{sc}}$ conformers is rather unorthodox, we already know that $\operatorname{PrP}$ can assume at least two profoundly different conformations: $\mathrm{PrP}^{\mathrm{C}}$ and $\mathrm{PrP}^{\mathrm{Sc}}{ }^{48)}$. Of note, two different isolates from mink dying of transmissible mink encephalopathy exhibit different sensitivities of $\mathrm{PrP}^{\mathrm{sc}}$ to proteolytic digestion, supporting the suggestion that isolate-specific information might be carried by $\operatorname{PrP}^{s c}{ }^{159-161)}$. How many conformations $\mathrm{PrP}^{\mathrm{Sc}}$ can assume is unknown. The molecular weight of a $\mathrm{PrP}^{\mathrm{sc}}$ homodimer is consistent with the ionizing radiation target size of $55,000 \pm 9000$ daltons as determined for infectious prion particles independent of their polymeric form ${ }^{162)}$. If prions are oligomers of $\mathrm{PrP}^{\mathrm{sc}}$, which seems likely, then this offers another level of complexity which in turn generates additional diversity.

\section{CONCLUSION}

Prions Are Not Viruses. The study of prions has taken several unexpected directions over the past few years. The discovery that prion diseases in humans are uniquely both genetic and infectious has greatly strengthened and extended the prion concept. To date, 18 different mutations in the human PrP gene all resulting in nonconservative substitutions have been found to either be linked genetically to or segregate with the inherited prion diseases. Yet, the transmissible prion particle is composed largely, if not entirely, of an abnormal isoform of the prion protein designated $\operatorname{Pr} \mathrm{P}^{\mathrm{sc}}{ }^{11}$. These findings argue that prion diseases should be considered pseudoinfections, since the particles transmitting disease appear to be devoid of a foreign nucleic acid and thus differ from all known microorganisms as well as viruses and viroids. Because much information, especially about scrapie of rodents, has been derived using experimental protocols adapted from virology, we continue to use terms such as infection, incubation period, transmissibility and endpoint titration in studies of prion diseases.

Do Prions Exist in Lower Organisms? In S. cervisiae, ure2 and [URE3] mutants were described that can grow on ureidosuccinate under conditions of nitrogen repression such as glutamic acid and ammonia ${ }^{163)}$. Mutants of URE2 exhibit Mendelian inheritance, whereas [URE3] is cytoplasmically inherited ${ }^{164)}$. The [URE3] phenotype can be induced by UV irradiation and by overexpression of ure2p, the gene product of ure 2 ; deletion of ure 2 abolishes [URE3]. The function of ure2p is unknown but it has substantial homology with glutathione-S-transferase; attempts to demonstrate this enzymic activity with purified ure2p have not been successful ${ }^{165)}$. Whether the [URE3] protein is a post-translationally modified form of ure2p which acts upon unmodified ure2p to produce more of itself remains to be established.

Another possible yeast prion is the [PSI] phenotype ${ }^{164)}$. [PSI] is a non-Mendelian inherited trait that can be induced by expression of the PNM2 gene ${ }^{166)}$. Both [PSI] and [URE3] can be cured by exposure of the yeast to $3 \mathrm{mM}$ GdnHCI. The mechanism responsible for abolishing [PSI] and

[URE3] with a low concentration of GdnHCI is unknown. In the filamentous fungus Podospora anserina, the het-s locus controls the vegetative incompatibility; conversion from the $S^{S}$ to the $s$ state seems to be a post-translational, autocatalytic process ${ }^{167)}$.

If any of the above cited examples can be shown to function in a manner similar to prions in animals, then many new, more rapid and economical approaches to prion diseases should be forthcoming . 
Common Neurodegenerative Diseases. The knowledge accrued from the study of prion diseases may provide an effective strategy for defining the etiologies and dissecting the molecular pathogenesis of the more common neurodegenerative disorders such as Alzheimer's disease, Parkinson's disease and amyotrophic lateral sclerosis (ALS). Advances in the molecular genetics of Alzheimer's disease and ALS suggest that, like the prion diseases, an important subset is caused by mutations that result in nonconservative amino acid substitutions in proteins expressed in the CNS ${ }^{168-175)}$. Since people at risk for inherited prion diseases can now be identified decades before neurologic dysfunction is evident, the development of an effective therapy is imperative.

Future Studies. Tg mice expressing foreign or mutant PrP genes now permit virtually all facets of prion diseases to be studied and have created a framework for future investigations. Furthermore, the structure and organization of the $\operatorname{PrP}$ gene suggested that $\operatorname{PrP}^{\mathrm{Sc}}$ is derived from $\mathrm{PrP}^{\mathrm{C}}$ or a precursor by a post-translational process. Studies with scrapie-infected cultured cells have provided much evidence that the conversion of $\operatorname{PrP}^{\mathrm{c}}$ to $\operatorname{PrP}^{\mathrm{sc}}$ is a post-translational process that probably occurs within a subcellular compartment bounded by cholesterol-rich membranes. The molecular mechanism of $\mathrm{PrP}^{\mathrm{sc}}$ formation remains to be elucidated, but chemical and physical studies have shown that the conformations of $\mathrm{PrP}^{\mathrm{c}}$ and $\mathrm{PrP}^{\mathrm{sc}}$ are profoundly different.

The study of prion biology and diseases seems to be a new and emerging area of biomedical investigation. While prion biology has its roots in virology, neurology and neuropathology, its relationships to the disciplines of molecular and cell biology as well as protein chemistry have become evident only recently. Certainly, the possibility that learning how prions multiply and cause disease will open up new vistas in biochemistry and genetics seems likely.

Acknowledgments : I thank M. Baldwin, D. Borchelt, G. Carlson, F. Cohen, C. Cooper, S. DeAr- mond, R. Fletterick, M. Gasset, R. Gabizon, D. Groth, R. Koehler, L. Hood, K. Hsiao, Z. Huang, V. Lingappa, K. -M. Pan, D. Riesner, M. Scott, A. Serban, N. Stahl, A. Taraboulos, M. Torchia, and D. Westaway for their help in these studies. Supported by grants from the National Institutes of Health (NS14069, AG08967, AG02132, NS22786 and AG10770) and the American Health Assistance Foundation, as well as by gifts from Sherman Fairchild Foundation and Bernard Osher Foundation.

\section{REFERENCES}

1) Prusiner, S. B. Molecular biology of prion diseases. Science, 252, 1515-1522, 1991.

2) Prusiner, S. B. Novel proteinaceous infectious particles cause scrapie. Science, 216, 136-144, 1982.

3) Alper, T., Haig, D. A., and Clarke, M. C. The exceptionally small size of the scrapie agent. Biochem. Biophys. Res. Commun., 22, 278-284, 1966.

4) Alper, T., Cramp, W. A., Haig, D. A., and Clarke, M. C. Does the agent of scrapie replicate without nucleic acid? Nature, 214, 764766, 1967.

5) Hunter, G. D. Scrapie: a prototype slow infection. J. Infect. Dis., 125, 427-440, 1972.

6) Riesner, D., Kellings, K., Meyer, N., Mirenda, C., and Prusiner, S. B. Nucleic acids and scrapie prions. In Prusiner, S. B., Collinge, J., Powell, J., and Anderton, B. (eds.) Prion.Diseases of Humans and Animals, pp. 341-358. (London: Ellis Horwood), 1992.

7) Prusiner, S. B., McKinley, M. P., Bowman, K. A., Bolton, D. C., Bendheim, P. E., Groth, D. F., and Glenner, G. G. Scrapie prions aggregate to form amyloid-like birefringent rods. Cell 35, 349-358, 1983.

8) Büeler, H., Aguzzi, A., Sailer, A., Greiner, R.-A., Autenried, P., Aguet, M., and Weissmann. C. Mice devoid of $\mathrm{PrP}$ are resistant to scrapie. Cell 73, 1339-1347, 1993.

9) Prusiner, S. B., Groth, D., Serban, A., Koehler, R., Foster, D., Torchia, M., Burton, D., Yang, S. -L., and DeArmond, S. J. Ablation of the prion 
protein $(\mathrm{PrP})$ gene in mice prevents scrapie and facilitates production of anti-PrP antibodies. Proc. Natl. Acad. Sci. USA, 90, 10608-10612, 1993.

10) Prusiner, S. B., Groth, D., Serban, A., Stahl, N., and Gabizon, R. Attempts to restore scrapie prion infectivity after exposure to protein denaturants. Proc. Natl. Acad. Sci. USA, 90, 2793-2797, 1993.

11) Sigurdsson, B. Rida, a chronic encephalitis of sheep with general remarks on infections which develop slowly and some of their special characteristics. Br. Vet J., 110, 341-354, 1954.

12) Gajdusek, D. C. Unconventional viruses and the origin and disappearance of kuru. Science, 197, 943-960, 1977.

13) Gajdusek, D.C. Subacute spongiform virus encephalopathies caused by unconventional viruses. In Maramorosch, K., and McKelvey, J.J., Jr. (eds.) Subviral Pathogens of Plants and Animals: Viroids and Prions, pp. 483-544. (Orlando: Academic Press), 1985.

14) Gajdusek, D. C., Gibbs, C. J., Jr., and Alpers, M. Experimental transmission of a kuru-like syndrome to chimpanzees. Nature, 209, 794-796, 1966.

15) Kirschbaum, W. R. Zwei eigenartige Erkrankungen des Zentralnervensystems nach Art der spastischen Pseudosklerose (Jakob). Z. Ges. Neurol. Psychiatr., 92, 175-220. 1924.

16) Meggendorfer, F. Klinische und genealogische Beobachtungen bei einem Fall von spastischer Pseudosklerose Jakobs. Z. Ges. Neurol. Psychiatr., 128, 337-341, 1930.

17) Sparkes, R. S., Simon, M., Cohn, V. H., Fournier, R. E. K., Lem, J., Klisak, I., Heinzmann. C., Blatt, C., Lucero, M., Mohandas, T., DeArmond, S. J., Westaway, D., Prusiner, S. B., and Weiner, L. P. Assignment of the human and mouse prion protein genes to homologous chromosomes. Proc. Natl. Acad. Sci. USA. 83, 7358-8362, 1986.

18) Hsiao, K., Baker, H. F., Crow, T. J., Poulter, M., Owen, F., Terwilliger, J. D., Westaway, D., Ott, J., and Prusiner, S. B. Linkage of a prion protein missense variant to Gerstmann-Sträussler syndrome. Nature, 338, 342-345, 1989.

19) Prusiner, S. B. Inherited prion diseases. Proc. Natl. Acad. Sci. USA, 91, 4611-4614, 1994.

20) Masters, C. L., Gajdusek, D. C., and Gibbs, C. J., Jr. Creutzfeldt-Jakob disease virus isolations from the Gerstmann-Sträussler syndrome. Brain, 104, 559-588, 1981.

21) Prusiner, S. B. Scrapie prions. Annu. Rev. Microbiol., 43, 345-374, 1989.

22) Tateishi, J., Doh-ura, K., Kitamoto, T., Tranchant, C., Steinmeiz, G., Warter, J. M., and Boellaard, J. W. Prion protein gene analysis and transmission studies of Creutzfeldt-Jakob disease. In Prusiner, S. B., Collinge, J., Powell, J., and Anderton, B. (eds.) Prion Diseases of Humans and Animals, pp. 129-134. (London: Ellis Horwood), 1992.

23) Malmgren, R., Kurland, L., Mokri, B., and Kurtzke, J. The epidemiology of CreufzfeldtJakob disease. In Prusiner, S. B., and Hadlow, W. J. (eds.) Slow Transmissible Diseases of the Nervous System, Vol. 1. pp. 93-112. (New York; Academic Press), 1979.

24) Brown, P., Cathala, F., Raubertas, R. F., Gajdusek, D. C., and Castaigne, P. The epidemiology of Creutzfeldt-Jakob disease: conclusion of 15-year investigation in France and review of the world literature. Neurology, 37, 895-904, 1987.

25) Harries-Jones, R., Knight, R., Will, R. G., Cousens, S., Smith, P. G., and Matthews, W. B. Creutzfeldt-Jakob disease in England and Wales, 1980-1984 : a case-control study of potential risk factors. J. Neurol. Neurosurg. Psychiatry, 51, 1113-1119, 1988.

26) Cousens, S. N., Harries-Jones, R., Knight, R., Will, R. G., Smith, P. G., and Matthews, W. B. Geographical distribution of cases of Creutzfeldt-Jakob disease in England and Wales 1970-84. J. Neurol. Neurosurg. Psychiatry, 53, 459-465, 1990.

27) Borchelt, D. R., Scott, M., Taraboulos, A., Stahl, N., and Prusiner, S. B. Scrapie and cellular prion proteins differ in their kinetics of synthesis and topology in cultured cells. J. Cell 
Biol., 110, 743-752, 1990.

28) Westaway, D., DeArmond, S. J., CayetanoCanlas, J., Groth, D., Foster, D., Yang, S.-L., Torchia, M., Carlson, G. A., and Prusiner, S. B. Degeneration of skeletal muscle, peripheral nerves, and the central nervous system in transgenic mice overexpressing wild-type prion proteins. Cell, 76, 117-129, 1994.

29) Masters, C. L., Harris. J. O., Gajdusek, D. C., Gibbs, C. J., Jr., Bernouilli, C., and Asher. D. M. Creutzfeldt-Jakob disease: patterns of worldwide occurrence and the significance of familial and sporadic clustering. Ann. Neurol., 5, 177188, 1978.

30) Gajdusek, D. C., and Zigas, V. Degenerative disease of the central nervous system in New Guinea - The endemic occurrence of "kuru" in the native population. N. Engl. J. Med., 257, 974978, 1957.

31) Gajdusek, D. C., and Zigas, V. Clinical, pathological and epidemiological study of an acute progressive degenerative disease of the central nervous system among natives of the eastern highlands of New Guinea. Am. J. Med., 26, 442469, 1959.

32) Alpers, M. Epidemiology and clinical aspects of kuru. In Prusiner, S. B., and McKinley, M. P. (eds.) Prions - Novel Infectious Pathogens Causing Scrapie and Creutzfeldt-Jakob Disease. pp. 451-465. (Orlando: Academic Press), 1987.

33) Hsiao, K., and Prusiner, S. B. Inherited human prion diseases. Neurology, 40, 1820-1827, 1990.

34) Brown. P. The phenotypic expression of different mutations in transmissible human spongiform encephalopathy. Rev. Neurol., 148, 317327, 1992.

35) Medori, R., Tritschier, H.-J., LeBlanc, A., Villare, F., Manetto, V., Chen, H. Y., Xue. R., Leal, S., Montagna, P., Cortelli, P., Tinuper, P., Avoni, P., Mochi, M., Baruzzi, A., Hauw. J. J., Ott, J., Lugaresi, E., Autilio-Gambetti, L., and Gambetti, P. Fatal familial insomnia, a prion disease with a mutation at codon 178 of the prion protein gene. N. Engl. J. Med., 326, 444449, 1992.
36) Hsiao, K. K., Scott, M., Foster, D., Groth, D. F., DeArmond, S. J., and Prusiner, S. B. Spontaneous neurodegeneration in transgenic mice with mutant prion protein. Science, 250, 1587-1590, 1990.

37) Hsiao, K. K., Groth, D., Scott. M., Yang, S.-L., Serban, H., Rapp, D., Foster, D., Torchia, M., DeArmond, S. J., and Prusiner, S. B. Serial transmission in rodents of neurodegeneration from transgenic mice expressing mutant prion protein. Proc. Natl. Acad. Sci. USA, 91, 91269130, 1994.

38) Telling, G. C., Scott, M., Foster, D., Yang S. -L., Torchia, M., Sidle, K. C. L. Collinge, J., DeArmond, S. J., and Prusiner, S. B. Transmission of Creutzfeldt-Jakob disease from humans to transgenic mice expressing chimeric human-mouse prion protein. Proc. Natl. Acad. Sci. USA, 91, 9936-9940, 1994.

39) Prusiner, S. B., Scott, M., Foster, D., Pan, K.-M., Groth, D., Mirenda, C., Torchia, M., Yang, S.-L., Serban, D., Carlson, G. A., Hoppe, P.C., Westaway, D., and DeArmond, S. J. Transgenetic studies implicate interactions between homologous $\operatorname{PrP}$ isoforms in scrapie prion replication. Cell, 63, 673-686, 1990.

40) Scott, M., Groth, D., Foster, D., Torchia, M., Yang, S.-L., DeArmond, S. J., and Prusiner. S. B. Propagation of prions with artificial properties in transgenic mice expressing chimeric PrP genes. Cell, 73, 979-988, 1993.

41) Stahl, N., Borchelt, D. R., Hsiao, K., and Prusiner, S. B. Scrapie prion protein contains a phosphatidylinositol glycolipid. Cell, 51, 229240, 1987.

42) Gordon, W. S. Advances in veterinary research. Vet. Res., 58, 516-520, 1946.

43) Parry, H, B. Scrapie Disease in Sheep, Oppenheimer, D. R. ed., pp. 192 pages. New York: Academic Press, 1983.

44) Parry, H. B. Scrapie : a transmissible and hereditary disease of sheep. Heredity, 17, 75-105, 1962.

45) Dickinson, A. G., Young, G. B., Stamp, J. T., and Renwick, C. C. An analysis of natural scrapie in Suffolk sheep. Heredity, 20, 485-503, 1965. 
46) Wilesmith, J. W., Ryan, J. B. M., Hueston, W. D., and Hoinville, L. J. Bovine spongiform encephalopathy: epidemiological features 1985 to 1990. Vet. Rec., 130, 90-94, 1992.

47) Stahl, N., Baldwin, M. A., Teplow, D. B., Hood, L., Gibson, B. W., Burlingame, A. L., and Prusiner, S. B. Structural analysis of the scrapie prion protein using mass spectrometry and amino acid sequencing. Biochemistry. 32, 19912002, 1993.

48) Pan, K.-M., Baldwin, M., Nguyen, J., Gasset, M., Serban, A., Groth, D., Mehlhorn, I., Huang, Z., Fletterick, R. J., Cohen, F. E., and Prusiner, S. B. Conversion of $\alpha$-helices into $\beta$-sheets features in the formation of the scrapie prion proteins. Proc. Natl. Acad. Sci. USA, 90, 10962 10966, 1993.

49) Caughey, B., and Raymond, G. J. The scrapieassociated form of $\operatorname{PrP}$ is made from a cell surface precursor that is both protease- and phospholipase-sensitive. J. Biol. Chem., 266, 18217-18223, 1991.

50) Borchelt, D. R., Taraboulos, A., and Prusiner, S. B. Evidence for synthesis of scrapie prion proteins in the endocytic pathway. J. Biol. Chem., 267, 16188-16199, 1992.

51) Taraboulos, A., Raeber, A. J., Borchelt, D. R., Serban, D., and Prusiner, S. B. Synthesis and trafficking of prion proteins in cultured cells. Mol. Biol. Cell, 3, 851-863 1992.

52) Keller, G. A., Siegel, M. W., and Caras, I. W. Endocytosis of glycophospholipid-anchored and transmembrane forms of CD4 by different endocytic pathways. EMBO J., 11, 863-874, 1992.

53) Anderson, R. G. W. Caveolae: where incoming and outgoing messengers meet, Proc. Natl. Acad. Sci. USA, 90, 10909-10913, 1993.

54) Haraguchi, T., Fisher, S., Olofsson, S., Endo, T., Groth, D., Tarantino, A., Borchelt, D. R., Teplow. D., Hood, L ., Burlingame, A., Lycke, E., Kobata, A., and Prusiner, S. B. Asparaginelinked glycosylation of the scrapie and cellular prion proteins. Arch. Biochem. Biophys., 274, 113, 1989.

55) Pan, K.-M., Stahl, N., and Prusiner, S. B. Purifi- cation and properties of the cellular prion protein from Syrian hamster brain. Protein Sci., 1, 1343-1352, 1992.

56) Borchelt, D. R., Rogers, M., Stahl, N., Telling, G., and Prusiner, S. B. Release of the cellular prion protein from cultured cells after loss of its glycoinositol phospholipid anchor. Glycobiology, 3, 319-329, 1993.

57) Caughey, B., Raymond, G. J., Emst, D., and Race, R. E. N-terminal truncation of the scrapie-associated form of $\operatorname{PrP}$ by lysosomal protease (s) : implications regarding the site of conversion of $\operatorname{PrP}$ to the protease-resistant state. J. Virol., 65, 6597-6603, 1991.

58) McKinley, M. P., Taraboulos, A., Kenaga, L., Serban, D., DeArmond, S. J., Stieber, A., and Prusiner, S. B. Ultrastructural localization of scrapie prion proteins in secondary lysosomes of infected cultured cells. J. Cell Biol., 316a, 1990.

59) McKinley, M. P., Meyer, R., Kenaga, L., Rahbar, F., Cotter, R., Serban, A., and Prusinet, S. B. Scrapie prion rod formation in vitro requires both detergent extraction and limited proteolysis. J. Virol., 65, 1440-1449, 1991.

60) Rogers, M., Yehiely, F., Scott, M., and Prusiner, S. B. Conversion of truncated and elongated prion proteins into the scrapie isoform in cultured cells. Proc. Natl. Acad. Sci. USA, 90, 31823186, 1993.

61) Taraboulos, A., Serban, D., and Prusiner, S. B. Scrapie prion proteins accumulate in the cytoplasm of persistently infected cultured cells. J. Cell Biol., 110, 2117-2132, 1990.

62) McKinley, M. P., Taraboulos, A., Kenaga, L., Serban, D., Stieber, A., DeArmond, S. J., Prusiner, S. B., and Gonatas, N. Ultrastructural localization of scrapie prion proteins in cytoplasmic vesicles of infected cultured cells. Lab. Invest., 65, 622-630, 1991.

63) Taraboulos, A., Rogers, M., Borchelt, D. R., McKinley, M. P., Scott, M., Serban, D., and Prusiner, S. B. Acquisition of protease resistance by prion proteins in scrapie-infected cells does not require asparagine-linked glycosyla- 
tion. Proc. Natl. Acad. Sci. USA, 87, 8262-8266, 1990.

64) Basler, K., Oesch, B., Scott, M., Westaway, D., Wälchli, M., Groth, D. F., McKinley, M. P., Prusiner, S. B., and Weissmann, C. Scrapie and cellular $\mathrm{PrP}$ isoforms are encoded by the same chromosomal gene. Cell, 46, 417-428, 1986.

65) Goldmann, W., Hunter, N., Multhaup, G., Salbalm, J. M., Foster, J. D., Beyreuther, K. T., and Hope. J. The $\operatorname{PrP}$ gene in natural scrapie. Alzheimer Disease and Associated Disorders [Abstract supplement]. 2, 330, 1988.

66) Goldmann, W., Hunter, N., Martin, T., Dawson, M., and Hope, J. Different forms of the bovine PrP gene have five or six copies of a short, G-C-rich element within the protein-coding exon. J. Gen. Virol., 72, 201-204, 1991.

67) Westaway D., Zuliani, V., Cooper, C. M., Da Costa, M., Neuman, S., Jenny, A. L., Detwiler, L., and Prusiner, S. B. Homozygosity for prion protein alleles encoding glutamine-171 renders sheep susceptible to natural scrapie. Genes Dev., 8, 959-969, 1994.

68) Westaway, D., Cooper, C., Turner, S., Da Costa, M., Carlson. G. A., and Prusiner, S. B. Structure and polymorphism of the mouse prion protein gene. Proc. Natl. Acad. Sci. USA, 91, 6418-6422, 1994.

69) Gasset, M., Baldwin, M. A., Lloyd, D., Gabriel, J.-M., Holtzman, D. M., Cohen, F., Fletterick, R., and Prusiner, S. B. Predicted $\alpha$-helical regions of the prion protein when synthesized as peptides form amyloid. Proc. Natl. Acad. Sci, USA, 89, 10940-10944, 1992.

70) Huang, Z., Gabriel, J.-M., Baldwin, M. A., Fletterick, R. J., Prusiner, S. B., and Cohen, F. E. Proposed three-dimensional structure for the cellular prion protein. Proc. Natl. Acad. Sci. USA, 91, 7139-7143, 1994.

71) Presnell, S. R., Cohen, B. I., and Cohen, F. E. MacMatch: a tool for pattern-based protein secondary structure prediction. Cabios, 9, 373374, 1993.

72) Kneller, D. G., Cohen, F. E., and Langridge, R. Improvement in protein secondary structure prediction by an enhanced neural network. J. Mol. Biol., 214, 171-182, 1990.

73) Turk, E., Teplow, D. B., Hood, L. E., and Prusiner, S. B. Purification and properties of the cellular and scrapie hamster prion proteins. Eur. J. Biochem., 176, 21-30, 1988.

74) Caughey, B. W., Dong, A., Bhat, K. S., Ernst, D., Hayes, S. F., and Caughey, W. S. Secondary structure analysis of the scrapie-associated protein $\operatorname{PrP} 27-30$ in water by infrared spectroscopy. Biochemistry, 30, 7672-7680, 1991.

75) Gasset, M., Baldwin, M. A., Fletterick, R. J., and Prusiner, S. B. Perturbation of the secondary structure of the scrapie prion protein under conditions associated with changes in infectivity. Proc. Natl. Acad. Sci. USA, 90, 1-5, 1993.

76) Safar, J., Roller, P. P., Gajdusek, D. C., and Gibbs, C. J., Jr. Conformational transitions, dissociation, and unfolding of scrapie amyloid (prion) protein. J. Biol. Chem., 268, 2027620284, 1993.

77) Safar, J., Roller, P. P., Gajdusek, D. C., and Gibbs, C. J. J. Thermal-stability and conformational transitions of scrapie amyloid (prion) protein correlate with infectivity. Protein Sci., 2, 2206-2216. 1993.

78) Selvaggini, C., De Gioja, L., Cantu, L., Ghibaudi, E., Diomede, L., Passerini, F., Forloni, G., Bugiani, O., Tagliavini, F., and Salmona, M. Molecular characteristics of a proteaseresistant, amyloidogenic and neurotoxic peptide homologous to residues 106-126 of the prion protein. Biochem. Biophys. Res. Commun., 194, 1380-1386, 1993.

79) Tagliavini, F., Prelli, F., Verga, L., Giaccone, G., Sarma, R., Gorevic, P., Ghetti, B., Passerini, F., Ghibaudi, E., Forloni, G., Salmona, M., Bugiani, O., and Frangione. B. Synthetic peptides homologous to prion protein residues 106-147 form amyloid-like fibrils in vitro. Proc. Natl. Acad. Sci. USA, 90, 9678-9682, 1993.

80) Goldfarb, L. G., Brown, P., Haltia, M., Ghiso, J., Frangione. B., and Gajdusek, D. C. Synthetic peptides corresponding to different mutated 
regions of the amyloid gene in familial Creutzfeldt-Jakob disease show enhanced in vitro formation of morphologically different amyloid fibrils. Proc. Natl. Acad. Sci. USA, 90, 4451-4454, 1993.

81) Come, J. H., Fraser, P. E., and Lansbury, P. T., Jr. A kinetic model for amyloid formation in the prion diseases: importance of seeding. Proc. Natl. Acad. Sci. USA, 90, 5959-5963, 1993.

82) Forloni, G., Angeretti, N., Chiesa, R., Monzani, E., Salmona, M., Bugiani, O., and Tagliavini, F. Neurotoxicity of a prion protein fragment. Nature, 362, 543-546, 1993.

83) Jarrett, J. T., and Lansbury, P. T., Jr. Seeding "one-dimensional crystallization" of amyloid : a pathogenic mechanism in Alzheimer's disease and scrapie? Cell, 73, 1055-1058, 1993.

84) Cohen, F. E., Pan, K.-M., Huang, Z., Baldwin, M., Fletterick, R. J., and Prusiner, S. B. Structural clues to prion replication. Science, 264, 530-531, 1994.

85) Safar, J., Roller, P. P., Gajdusek, D. C., and Gibbs, C. J., Jr. Scrapie amyloid (prion) protein has the conformational characteristics of an aggregated molten globule folding intermediate. Biochemistry, 33, 8375-8383, 1994.

86) Kocisko, D. A., Come, J. H., Priola, S. A., Chesebro, B., Raymond, G. J., Lansbury, P. T., Jr., and Caughey, B. Cell-free formation of protease-resistant prion protein. Nature, 370, 471-474, 1994.

87) Raeber, A. J., Borchelt, D. R., Scott, M., and Prusiner, S. B. Attempts to convert the cellular prion protein into the scrapie isoform in cellfree systems. J. Virol., 66, 6155-6163, 1992.

88) Gajdusek, D. C. Transmissible and nontransmissible amyloidoses: autocatalytic posttranslational conversion of host precursor proteins to $\beta$-pleated sheet configurations. J. Neuroimmunol., 20, 95-110, 1988.

89) Gajdusek, D. C. Subacute spongiform encephalopathies: transmissible cerebral amyloidoses caused by unconventional viruses. In Fields, B. N., Knipe, D. M., Chanock, R. M., Hirsch, M. S., Melnick, J. L., Monath, T. P., and
Roizman. B. (eds.) Virology, 2nd Ed., pp. 22892324, (New York: Raven Press), 1990.

90) Gajdusek, D. C., and Gibbs. C. J., Jr. Brain amyloidoses-precursor proteins and the amyloids of transmissible and nontransmissible dementias: scrapie-kuru CJD viruses as infectious polypeptides or amyloid enhancing vector. In Goldstein, A. (ed.) Biomedical Advances in Aging, pp. 3-24. (New York: Plenum Press), 1990.

91) Glenner, G. G., Eanes, E. D., Bladen, H. A., Linke, R. P., and Termine, J. D. Beta-pleated sheet fibrils - a comparison of native amyloid with synthetic protein fibrils. J. Histochem. Cytochem., 22, 1141-1158, 1974.

92) Glenner, G. G. Amyloid deposits and amyloidosis, N. Engl. J. Med., 302, 1283-1292, 1980.

93) Gabizon, R., McKinley, M. P., and Prusiner, S. B. Purified prion proteins and scrapie infectivity copartition into liposomes. Proc. Natl. Acad. Sci. USA, 84, 4017-4021, 1987.

94) Gabizon, R., Rosenmann, H., Meiner, Z., Kahana, I., Kahana, E., Shugart, Y., Ott, J., and Prusiner, S. B. Mutation and polymorphism of the prion protein gene in Libyan Jews with Creutzfeldt-Jakob disease. Am. J. Hum. Genet., 33, 828-835, 1993.

95) Kitamoto, T., and Tateishi, J. Human prion diseases with variant prion protein. Phil. Trans. R. Soc. Lond. B, 343, 391-398, 1994.

96) Brown, P., Preece, M. A., and Will, R. G. "Friendly fire" in medicine: hormones, homografts, and Creutzfeldt- Jakob disease. Lancet, 340, 24-27, 1992.

97) Wilesmith, J. W. Bovine spongiform encephalopathy : a brief epidemiography, 1985-1991. In Prusiner, S. B., Collinge, J., Powell, J., and Anderton, B. (eds.) Prion Diseases of Humans and Animals, pp. 243-255. (London: Ellis Horwood), 1992.

98) Palmer, M. S., Dryden, A. J., Hughes, J. T., and Collinge, J. Homozygous prion protein genotype predisposes to sporadic CreutzfeldtJakob disease. Nature, 352, 340-342, 1991. 
99) Lifson, S., and Sander, C. Composition, cooperativity and recognition in proteins. In Jaenicke, FL. (ed.) Protein Folding, pp. 289-314. (Amsterdam: Elsevier/North-Holland Biomedical Press), 1980.

100) Goldfarb, L. G., Petersen, R. B., Tabaton, M., Brown, P., LeBlanc, A. C., Montagna, P., Cortelli, P., Julien, J., Vital, C., Pendelbury, W. W., Haltia, M., Wills, P. R., Hauw. J. J., McKeever, P. E., Monari, L., Schrank, B., Swergold G. D., Autilio-Gambetti, L., Gajdusek, D. C., Lugaresi, E., and Gambetti, P. Fatal familial insomnia and familial Creutzfeldt-Jakob disease : disease phenotype determined by a DNA polymorphism. Science, 258, 806-808, 1992.

101) Monari, L., Chen, S. G., Brown, P., Parchi, P., Petersen, R. B., Mikol, J., Gray, F., Cortelli, P., Montagna, P., Ghetti, B., Goldfarb. L. G., Gajdusek, D. C., Lugaresi, E., Gambetti, P., and Autilio-Gambetti, L. Fatal familial insomnia and familial Creutzfeldt-Jakob disease : different prion proteins determined by a DNA polymorphism. Proc. Natl. Acad. Sci. USA, 91, 2839-2842, 1994.

102) Kretzschmar, H. A., Stowring, L. E., Westaway, D., Stubblebine, W. H., Prusiner, S. B., and DeArmond, S. J. Molecular cloning of a human prion protein cDNA. DNA, 5, 315-324, 1986.

103) Dlouhy, S. R., Hsiao, K., Farlow, M. R., Foroud, T., Conneally, P. M., Johnson, P., Prusiner, S. B., Hodes. M. E., and Ghetti, B. Linkage of the Indiana kindred of Gerstmann-SträusslerScheinker disease to the prion protein gene. Nat. Genet., 1, 64-67, 1992.

104) Petersen, R. B., Tabaton, M., Berg, L., Schrank, B., Torack, R. M., Leal, S., Julien, J., Vital, C., Deleplanque, B., Pendlebury, W. W., Drachman, D., Smith, T. W., Martin, J. J., Oda, M., Montagna, P., Ott, J., Autilio-Gambetti, L., Lugaresi, E., and Gambetti, P. Analysis of the prion protein gene in thalamic dementia. Neurology, 42, 1859-1863, 1992.

105) Poulter, M., Baker, H. F., Frith, C. D., Leach, M., Lofthouse. R., Ridley, R. M., Shah, T., Owen, F., Collinge, J., Brown, G., Hardy, J.,
Mullan, M. J., Harding, A. E., Bennett, C., Doshi, R., and Crow, T. J. Inherited prion disease with 144 base pair gene insertion. 1. Genealogical and molecular studies. Brain, 115, 675685, 1992.

106) Brown, P., Gibbs, C. J., Jr., Rodgers-Johnson, P., Asher, D. M., Sulima, M. P., Bacote, A., Goldfarb, L. G., and Gajdusek, D. C. Human spongiform encephalopathy : the National Institutes of Health series of 300 cases of experimentally transmitted disease. Ann. Neurol., 35, 513-529. 1994.

107) Pattison, I. H. Experiments with scrapie with special reference to the nature of the agent and the pathology of the disease. In Gajdusek, D. C., Gibbs, C. J., Jr., and Alpers, M. P. (eds.) Slow, Latent and Temperate Virus Infections, NINDB Monograph 2, pp. 249-257. (Washington, D. C. : U.S. Govermment Printing). 1965.

108) Pattison, I. H. The relative susceptibility of sheep, goats and mice to two types of the goat scrapie agent. Res. Vet. Sci., 7, 207-212, 1966.

109) Pattison, I. H., and Jones, K. M. The possible nature of the transmissible agent of scrapie. Vet. Rec., 80, 1-8, 1967.

110) Bockman, J. M., Prusiner, S. B., Tateishi, J., and Kingsbury, D. T. Immunoblotting of Creutzfeldt-Jakob disease prion proteins : host species-specific epitopes. Ann. Neurol., 21. 589595, 1987.

111) Wilesmith, J. W., Hoinville, L. J., Ryan, J. B. M., and Sayers, A. R. Bovine spongiform encephalopathy: aspects of the clinical picture and analyses of possible changes 1986-1990. Vet. Rec., 130, 197-201, 1992.

112) Hope, J., Reekie, L. J. D., Hunter, N., Multhaup, G., Beyreuther, K., White, H., Scott. A. C., Stack, M. J., Dawson, M., and Wells, G. A. H. Fibrils from brains of cows with new cattle disease contain scrapie-associated protein. Nature, 336, 390-392, 1988.

113) Prusiner, S. B., Fuzi, M., Scott, M., Serban, D., Serban, H., Taraboulos, A., Gabriel, J.-M., Wells, G., Wilesmith, J., Bradley, R., DeArmond, S. J., and Kristensson, K. Immunologic 
and molecular biological studies of prion proteins in bovine spongiform encephalopathy. J. Infect. Dis., 167, 602-613, 1993.

114)Scott, M., Foster, D., Mirenda, C., Serban, D., Coufal, F., Wälchli, M., Torchia, M., Groth, D., Carlson, G., DeArmond, S. J., Westaway, D., and Prusiner, S. B. Transgenic mice expressing hamster prion protein produce species $\sim$ specific scrapie infectivity and amyloid plaques. Cell, 59, 847-857, 1989.

115) Büeler, H., Fischer, M., Lang, Y., Bluethmann, H., Lipp, H.-P., DeArmond, S. J., Prusiner. S. B., Aguet, M., and Weissmann, C. Normal development and behaviour of mice lacking the neuronal cell-surface PrP protein. Nature, 356, 577-582, 1992.

116) Barry, R. A., and Prusiner, S. B. Monoclonal antibodies to the cellular and scrapie prion proteins. J. Infect. Dis., 154, 518-521, 1986.

117) Kascsak, R. J., Rubenstein, R., Merz, P. A., Tonna-DeMasi, M., Fersko, R., Carp, R. I., Wisniewski, H. M., and Diringer, H. Mouse polyclonal and monoclonal antibody to scrapieassociated fibril proteins. J. Virol., 61, 36883693, 1987.

118) Rogers, M., Serban, D., Gyuris, T., Scott, M., Torchia, T., and Prusiner, S. B. Epitope mapping of the Syrian hamster prion protein utilizing chimeric and mutant genes in a vaccinia virus expression system. J. Immunol., 147, 35683574, 1991.

119) Brown, P., Goldfarb, L. G., Kovanen, J., Haltia, M., Cathala, F., Sulima, M., Gibbs, C. J., Jr., and Gajdusek, D. C. Phenotypic characteristics of familial Creutzfeldt-Jakob disease associated with the codon 178 Asn PRNP mutation. Ann. Neurol., 31, 282-285, 1992.

120) Medori, R., Montagna, P., Trischler, H. J., LeBlanc, A., Cortelli, P., Tinuper, P., Lugaresi. E., and Gambetti, P. Fatal familial insomnia : a second kindred with mutation of prion protein gene at codon 178. Neurology, 42, 669-670, 1992.

121) Carlson, G. A., Ebeling, C., Yang, S.-L., Telling, G., Torchia, M., Groth, D., Westaway, D., DeArmond, S. J., and Prusiner, S. B. Prion isolate specified allotypic interactions between the cellular and scrapie prion proteins in congenic and transgenic mice. Proc. Natl. Acad. Sci. USA, 91, 5690-5694, 1994.

122) Scott, M. R., Köhler, R., Foster, D., and Prusiner, S. B. Chimeric prion protein expression in cultured cells and transgenic mice. Protein Sci., 1, 986-997, 1992.

123) Oesch, B., Teplow, D. B., Stahl. N., Serban, D., Hood, L. E., and Prusiner, S. B. Identification of cellular proteins binding to the scrapie prion protein. Biochemistry, 29, 5848-5855, 1990.

124) Carlson, G. A., Ebeling, C., Torchia, M., Westaway, D., and Prusiner, S. B. Delimiting the location of the scrapie prion incubation time gene on chromosome 2 of the mouse. Genetics, 133, 979-988, 1993.

125) Bruce, M. E., Dickinson, A. G., and Fraser, H. Cerebral amyloidosis in scrapie in the mouse: effect of agent strain and mouse genotype. Neuropathol. Appl. Neurobiol., 2, 471-478, 1976.

126) Cuillé, J., and Chelle, P. L. Experimental transmission of trembling to the goat. C. R. Seances Acad. Sci., 208, 1058-1060, 1939.

127) Dickinson, A. G., and Stamp, J. T. Experimental scrapie in Cheviot and Suffolk sheep. J. Comp. Pathol., 79, 23-26, 1969.

128) Hadlow, W. J., Kennedy, R. C., and Race, R. E. Natural infection of Suffolk sheep with scrapie virus. J. Infect. Dis., 146, 657-664, 1982.

129) Hadlow, W. J., Kennedy, R. C., Race, R. E., and Eklund, C. M. Virologic and neurohistologic findings in dairy goats affected with natural scrapie. Vet. Pathol., 17, 187-199, 1980.

130) Gordon, W. S. Variation in susceptibility of sheep to scrapie and genetic implications. In Report of Scrapie Seminar, ARS 91-53, pp. 5367. (Washington, D. C. : U.S. Department of Agriculture), 1966.

131) Pattison, I. H., and Millson, G. C. Scrapie produced experimentally in goats with special reference to the clinical syndrome. J. Comp. Pathol., 71, 101-108, 1961.

132) Dickinson, A. G., and Fraser, H. An assessment of the genetics of scrapie in sheep and 
mice. In Prusiner, S. B., and Hadlow, W. J. (eds.) Slow Transmissible Diseases of the Nervous System, Vol. 1, pp. 367-386. (New York: Academic Press), 1979.

133) Bruce, M. E., and Dickinson, A. G. Biological evidence that the scrapie agent has an independent genome. J. Gen. Virol., 68, 79-89, 1987.

134) Kimberlin, R. H., Cole, S., and Walker, C. A. Temporary and permanent modifications to a single strain of mouse scrapie on transmission to rats and hamsters. J. Gen. Virol., 68, 18751881, 1987.

135) Dickinson, A. G., and Outram, G. W. Genetic aspects of unconventional virus infections: the basis of the virino hypothesis. In Bock, G., and Marsh, J. (eds.) Novel Infectious Agents and the Central Nervous System. Ciba Foundation Symposium 135, pp. 63-83. (Chichester, UK : John Wiley and Sons), 1988.

136) Dickinson, A. G., Meikle, V. M. H., and Fraser, $H$. Identification of a gene which controls the incubation period of some strains of scrapie agent in mice. J. Comp. Pathol., 78, 293-299, 1968.

137) Fraser, H., and Dickinson, A. G. Scrapie in mice. Agent-strain differences in the distribution and intensity of grey matter vacuolation. J. Comp. Pathol., 83, 29-40, 1973.

138) Bruce, M. E., McBride, P. A., and Farquhar, C. F. Precise targeting of the pathology of the sialoglycoprotein, $\operatorname{PrP}$, and vacuolar degeneration in mouse scrapie. Neurosci. Lett., 102, 1-6, 1989.

139) Hecker, R., Taraboulos, A., Scott, M., Pan, K.-M., Torchia, M., Jendroska, K., DeArmond. S. J., and Prusiner, S. B. Replication of distinct prion isolates is region specific in brains of transgenic mice and hamsters. Genes Dev., 6, 1213-1228, 1992.

140) Dickinson, A. G., and Meikle, V. M. H. Hostgenotype and agent effects in scrapie incubation : change in allelic interaction with different strains of agent. Mol. Gen. Genet., 112, 73-79, 1971.

141) Dickinson. A. G., Bruce, M. E., Outram, G. W., and Kimberlin, R. H. Scrapie strain differences: the implications of stability and mutation. In Tateishi, J. (ed.) Proceedings of Workshop on Slow Transmissible Diseases, pp. 105-118. (Tokyo: Japanese Ministry of Health and Welfare), 1984.

142) Kingsbury, D. T., Kasper, K. C., Stites, D. P., Watson, J. D., Hogan, R. N., and Prusiner. S. B. Genetic control of scrapie and CreutzfeldtJakob disease in mice. J. Immunol., 131, 491-496, 1983.

143)Carp, R. I., Moretz, R. C., Natelli, M., and Dickinson, A. G. Genetic control of scrapie: incubation period and plaque formation in mice. J. Gen. Virol., 68, 401-407. 1987.

144) Carlson, G. A., Kingsbury, D. T., Goodman, P. A., Coleman, S., Marshall, S. T., DeArmond, S. J., Westaway, D., and Prusiner, S. B. Linkage of prion protein and scrapie incubation time genes. Cell, 46, 503-511, 1986.

145) Hunter, N., Hope, J., McConnell, I., and Dickinson, A. G. Linkage of the scrapie-associated fibril protein $(\mathrm{PrP})$ gene and Sinc using congenic mice and restriction fragment length polymorphism analysis. J. Gen. Virol., 68, 2711-2716, 1987.

146) Race, R. E., Graham, K., Ernst, D., Caughey, B., and Chesebro, B. Analysis of linkage between scrapie incubation period and the prion protein gene in mice. J. Gen. Virol., 71, 493-497, 1990.

147) O'Brien, S. J. In Genetic Maps - Locus Maps of Complex Genomes, 6th Edition, pp. 4. 42-4. 45. (Cold Spring Harbor, NY : Cold Spring Harbor Laboratory Press), 1993.

148) Westaway, D., Goodman, P. A., Mirenda, C. A., McKinley, M. P., Carlson, G. A., and Prusiner, S. B. Distinct prion proteins in short and long scrapie incubation period mice. Cell, 51, 651-662, 1987.

149) Westaway, D., Mirenda, C. A., Foster, D., Zebarjadian, Y., Scott, M., Torchia, M., Yang, S.-L., Serban, H., DeArmond, S. J., Ebeling, C., Prusiner, S. B., and Carlson, G. A. Paradoxical shortening of scrapie incubation times by expression of prion protein transgenes derived from long incubation period mice. Neuron, 7 , 
59-68, 1991.

150) Carlson, G. A., Westaway, D., DeArmond, S. J., Peterson-Torchia, M., and Prusiner, S. B. Primary structure of prion protein may modify scrapie isolate properties. Proc. Natl. Acad. Sci. USA, 86, 7475-7479, 1989.

151)Dickinson, A. G., and Meikle, V. M. A comparison of some biological characteristics of the mouse-passaged scrapie agents, 22A and ME7. Genet. Res., 13, 213-225, 1969.

152)Dickinson, A. G., and Outram, G. W. The scrapie replication-site hypotheses and its implications for pathogenesis. In Prusiner, S. B., and Hadlow, W. J. (eds.) Slow Transmissible Diseases of the Nervous System, Vol. 2, pp. 13-31. (New York: Academic Press), 1979.

153) Fraser, H. Neuropathology of scrapie : the precision of the lesions and their diversity. In Prusiner, S. B., and Hadlow, W. J. (eds.) Slow Transmissible Diseases of the Nervous System, Vol. 1, pp. 387-406. (New York: Academic Press), 1979.

154) Taraboulos, A., Jendroska, K., Serban, D., Yang, S.-L., DeArmond, S. J., and Prusiner, S. B. Regional mapping of prion proteins in brains. Proc. Natl. Acad. Sci. USA, 89, 7620-7624, 1992.

155) DeArmond, S. J., Yang, S.-L., Lee, A., Bowler, R., Taraboulos, A., Groth, D., and Prusiner, S. B. Three scrapie prion isolates exhibit different accumulation patterns of the prion protein scrapie isoform. Proc. Natl. Acad. Sci. USA, 90, 6449-6453, 1993.

156) DeArmond, S. J., Mobley, W. C., DeMott, D. L., Barry, R. A., Beckstead, J. H., and Prusiner. S. B. Changes in the localization of brain prion proteins during scrapie infection. Neurology, 37, 1271-1280, 1987.

157) Casaccia-Bonnefil, P., Kascsak, R. J., Fersko, R., Callahan, S., and Carp, R. I. Brain regional distribution of prion protein PrP27-30 in mice stereotaxically microinjected with different strains of scrapie. J. Infect. Dis., 167, 7-12, 1993.

158) Bruce. M. E., McConnell, I., Fraser. H., and Dickinson, A. G. The disease characteristics of different strains of scrapie in Sinc congenic mouse lines: implications for the nature of the agent and host control of pathogenesis. J. Gen. Virol. 72, 595-603, 1991.

159) Marsh, R. F., Bessen, R. A., Lehmann, S., and Hartsough, G. R. Epidemiological and experimental studies on a new incident of transmissible mink encephalopathy. J. Gen. Virol., 72, 589594, 1991.

160) Bessen, R. A., and Marsh, R. F. Biochemical and physical properties of the prion protein from two strains of the transmissible mink encephalopathy agent. J. Virol., 66, 2096-2101, 1992.

161) Bessen, R. A., and Marsh, R. F. Identification of two biologically distinct strains of transmissible mink encephalopathy in hamsters. J. Gen. Virol., 73, 329-334, 1992.

162) Bellinger-Kawahare, C. G., Kempner, E., Groth, D. F., Gabizon, R., and Prusiner, S. B. Scrapie prion liposomes and rods exhibit target sizes of 55,000 Da. Virology, 164, 537-541, 1988.

163) Lacroute, F. Non-Mendelian mutation allowing ureidosuccinic acid uptake in yeast. J. Bacteriol., 106, 519-522, 1971.

164) Wickner, R. B. Evidence for a prion analog in $S$. cerevisiae: the [URE3] non-Mendelian genetic element as an altered URE2 protein. Science, in press, 1994.

165) Coschigano, P. W., and Magasanik, B. The URE2 gene product of Saccharomyces cerevisiae plays an important role in the cellular response to the nitrogen source and has homology to glutathione S-transferases. Mol. Cell. Biol., 11, 822-832, 1991.

166) Cox, B. S., Tuite, M. F., and McLaughlin, C. S. The psi factor of yeast: a problem in inheritance. Yeast, 4, 159-178, 1988.

167) Deleu, C., Clavé, C., and Bégueret, J. A single amino acid difference is sufficient to elicit vegetative incompatibility in the fungus Podospora anserina. Genetics, 135, 45-52, 1993.

168) Schellenberg, G. D., Bird, T. D., Wijsman, E. M., Orr, H. T., Anderson, L., Nemens, E., White, J. A., Bonnycastle, L., Weber, J. L., Alonso, M. E., Potter, H., Heston, L. L., and Martin, G. M. 
Genetic linkage evidence for a familial $\mathrm{Alz}$ heimer's disease locus on chromosome 14. Science, 258, 668-671, 1992.

169) Van Broeckhoven, C., Backhovens, H., Cruts. M., De Winter, G., Bruyland, M., Cras, P., and Martin, J.-J. Mapping of a gene predisposing to early-onset Alzheimer's disease to chromosome 14q24.3. Nat. Genet., 2, 335-339, 1992.

170) Van Broeckhoven, C., Haan, J., Bakker, E., Hardy, J. A., Van Hul, W., Wehnert, A. VegterVan der Vlis, M., and Roos, R. A. Amyloid $\beta$ protein precursor gene and hereditary cerebral hemorrhage with amyloidosis (Dutch). Science, 248, 1120-1122, 1990.

171) Rosen, D. R., Siddique, T., Patterson, D., Figiewicz, D. A., Sapp, P., Hentati, A., Donaldson, D., Goto, J., O’Regan, J. P., Deng, H. -., Rahmani, Z., Krizus, A., McKenna-Yasek, D., Cayabyab, A., Gaston, S. M., Berger, R., Tanzi, R. E., Halperin, J. J., Herzfeldt, B., Van den Bergh, R., Hung, W.-Y., Bird, T., Deng, G., Mulder, D. W., Smyth, C., Laing, N. G., Soriano, E., Pericak-Vance, M. A., Haines, J., Rouleau, G, A., Gusella, J. S., Horvitz, H. R., and Brown. R. H., Jr. Mutations in $\mathrm{Cu} / \mathrm{Zn}$ superoxide dismutase gene are associated with familial amyotrophic lateral sclerosis. Nature, 362, 5962, 1993.

172) Mullan, M., Houlden, H., Windelspecht, M., Fidani, L., Lombardi, C., Diaz, P., Rossor, M., Crook, R., Hardy, J., Duff, K., and Crawford, F. A locus for familial early-onset Alzheimer's disease on the long arm of chromosome 14, proximal to the $\alpha 1$-antichymotrypsin gene. Nat. Genet., 2, 340-342, 1992.

173) Goate, A., Chartier-Harlin, M.-C., Mullan, M., Brown, J., Crawford, F., Fidani, L., Giuffra. L., Haynes, A., Irving, N., James, L., Mant, R., Newton, P., Rooke, K., Roques, P., Talbot, C., Pericak-Vance, M., Roses, A., Williamson, R., Rossor, M., Owen, M., and Hardy. J. Segregation of a missense mutation in the amyloid precursor protein gene with familial Alzheimer' s disease. Nature, 349, 704-706, 1991.

174) St. George-Hyslop, P., Haines, J., Rogaev, E.
Mortilla, M., Vaula, G., Pericak-Vance, M., Foncin, J.-F., Montesi, M., Bruni, A., Sorbi, S., Rainero, I., Pinessi, L., Pollen, D., Polinsky, R., Nee, L., Kennedy, J., Macciardi, F., Rogaeva, E., Liang, Y., Alexandrova, N., Lukiw, W., Schlumpf, K., Tanzi, R., Tsuda, T., Farrer, L., Cantu, J.-M., Duara, R., Amaducci, L., Bergamini, L., Gusella, J., Roses. A., and McLachlan, D. C. Genetic evidence for a novel familial Alzheimer's disease locus on chromosome 14 . Nat. Genet., 2, 330-334, 1992.

175) Levy, E., Carman, M. D., Fernandez-Madrid, I. J., Power, M. D., Lieberburg, I., van Duinen, S. G., Bots, G. T. A. M., Luyendijk, W., and Frangione, $\mathrm{B}$. Mutation of the Alzheimer's disease amyloid gene in hereditary cerebral hemorrhage, Dutch type. Science, 248, 1124-1126, 1990.

176) Bolton, D. C., McKinley, M. P., and Prusiner, S. B. Identification of a protein that purifies with the scrapie prion. Science, 218, 1309-1311, 1982.

177) Prusiner, S. B., Bolton, D. C., Groth, D. F., Bowman, K. A., Cochran, S. P., and McKinley, M. P. Further purification and characterization of scrapie prions. Biochemistry, 21, 6942-6950, 1982 .

178) McKinley, M. P., Bolton, D. C., and Prusiner, S. B. A protease-resistant protein is a structural component of the scrapie prion. Cell, 35, 57-62, 1983.

179) Hope, J., Morton, L. J. D., Farquhar, C. F., Multhaup, G., Beyreuther, K., and Kimberlin, R, $H$. The major polypeptide of scrapie-associated fibrils (SAF) has the same size, charge distribution and $\mathrm{N}$-terminal protein sequence as predicted for the normal brain protein $(\mathrm{PrP})$. EMBO J., 5, 2591-2597, 1986.

180) Safar, J., Wang, W., Padgett, M. P., Ceroni, M., Piccardo, P., Zopf, D., Gajdusek, D. C., and Gibbs, C. J., Jr. Molecular mass, biochemical composition, and physicochemical behavior of the infectious form of the scrapie precursor protein monomer. Proc. Natl. Acad. Sci. USA, 87, 6373-6377, 1990.

181) Jendroska, K., Heinzel, F. P., Torchia, M., Stowring, L., Kretzschmar, H. A., Kon, A., 
Stern, A., Prusiner, S. B., and DeArmond, S. J. Proteinase-resistant prion protein accumulation in Syrian hamster brain correlates with regional pathology and scrapie infectivity. Neurology, 41, 1482-1490, 1991.

182) Gabizon, R., McKinley, M. P., Groth, D. F., and Prusiner, S. B. Immunoaffinity purification and neutralization of scrapie prion infectivity. Proc. Natl. Acad. Sci. USA, 85, 6617-6621, 1988.

183) Gabizon, R., and Prusiner, S. B. Prion liposomes. Biochem. J., 266, 1-14, 1990.

184) Butler, D. A., Scott, M. R. D., Bockman, J. M., Borchelt, D. R., Taraboulos, A., Hsiao, K, K., Kingsbury, D. T., and Prusiner, S. B. Scrapieinfected murine neuroblastoma cells produce protease-resistant prion proteins. J. Virol., 62, 1558-1564, 1988.

185) Bendheim, P. E., Barry, R. A., DeArmond, S. J., Stites, D. P., and Prusiner, S. B. Antibodies to a scrapie prion protein, Nature, 310, 418-421, 1984.

186) DeArmond, S. J., McKinley, M. P., Barry, R. A., Braunfeld, M. B., McColloch, J. R., and Prusiner, S. B. Identification of prion amyloid filaments in scrapie-infected brain. Cell, 41, 221235, 1985.

187) Kitamoto, T., Tateishi, J., Tashima, I., Takeshita, I., Barry. R. A., DeArmond, S. J., and Prusiner, S. B. Amyloid plaques in CreutzfeldtJakob disease stain with prion protein antibodies. Ann. Neurol., 20, 204-208, 1986.

188) Roberts, G. W., Lofthouse, R., Allsop, D., Landon, M., Kidd, M., Prusiner, S. B., and Crow. T. J. CNS amyloid proteins in neurodegenerative diseases. Neurology, 38, 1534-1540, 1988.

189) Bockman, J. M., Kingsbury, D. T., McKinley, M. P., Bendheim, P. E., and Prusiner, S. B. Creutzfeldt-Jakob disease prion proteins in human brains. N. Engl. J. Med., 312, 73-78, 1985.

190) Brown, P., Coker-Vann, M., Pomeroy, K., Franko, M., Asher, D. M., Gibbs, C. J., Jr., and Gajdusek, D. C. Diagnosis of Creutzfeldt-Jakob disease by Western blot indentification of marker protein in human brain tissue. N. Engl. J. Med., 314, 547-551, 1986.

191) Serban, D., Taraboulos, A., DeArmond, S. J., and Prusiner, S. B. Rapid detection of Creutzfeldt-Jakob disease and scrapie prion proteins. Neurology, 40, 110-117, 1990.

192) Carlson, G. A., Goodman, P. A., Lovett, M., Taylor, B. A., Marshall, S. T., PetersonTorchia, M., Westaway, D., and Prusiner, S. B. Genetics and polymorphism of the mouse prion gene complex : the control of scrapie incubation time. Mol. Cell. Biol., 8, 5528-5540. 1988.

193) Prusiner, S. B. Molecular biology and genetics of neurodegenerative diseases caused by prions. Adv. Virus Res., 41, 241-280. 1992.

194) Prusiner, S. B., and Hsiao. K. K. Human prion diseases. Ann. Neurol., 35, 385-395, 1994.

195) Puckett, C., Concannon, P., Casey, C., and Hood, L. Genomic structure of the human prion protein gene. Am. J. Hum. Genet, 49, 320-329, 1991.

196) Vnencak-Jones, C. L., and Phillips, J. A. Identification of heterogeneous PrP gene deletions in controls by detection of allele-specific heteroduplexes (DASH). Am. J. Hum. Genet., 50. 871872, 1992.

197) Laplanche, J.-L., Chatelain, J., Launay, J.-M., Gazengel, C., and Vidaud, M. Deletion in prion protein gene in a Moroccan family. Nucleic Acids. Res., 182, 6745, 1990.

198) Owen, F., Poulter, M., Lofthouse, R., Collinge, J., Crow, T. J., Risby, D., Baker, H. F., Ridley, R. M., Hsiao, K., and Prusiner, S. B. Insertion in prion protein gene in familial Creutzfeldt-Jakob disease. Lancet, 1, 51-52, 1989.

199) Owen, F., Poulter, M., Shah, T., Collinge, J., Lofthouse, R., Baker, H., Ridley, R., McVey, J., and Crow, T. An in-frame insertion in the prion protein gene in familial Creutzfeldt-Jakob disease. Mol. Brain Res., 7, 273-276, 1990.

200) Collinge, J., Harding, A, E., Owen, F., Poulter, M., Lofthouse, R., Boughey, A. M., Shah, T., and Crow, T. J. Diagnosis of GerstmannSträussler syndrome in familal dementia with prion protein gene analysis. Lancet. 2, 15-17, 1989.

201) Collinge, J., Owen, F., Poulter, H., Leach, M., Crow, T., Rosser, M., Hardy, J., Mullan, H., 
Janota, I., and Lantos, P. Prion dementia without characteristic pathology. Lancet, 336, 7-9, 1990 .

202) Crow, T. J., Collinge, J., Ridley, R. M., Baker, H. F., Lofthouse, R., Owen, F., and Harding, A. E. Mutations in the prion gene in human transmissible dementia. Seminar on Molecular Approaches to Research in Spongiform Encephalopathies in Man, Medical Research Council, London, Dec, 14, 1990 (Abstr.), 1990.

203) Goldfarb, L. G., Brown, P., Goldgaber, D., Asher, D. M., Rubenstein, R., Brown, W. T., Piccardo, P., Kascsak, R. J., Boellaard, J. W., and Gajdusek, D. C. Creutzfeldt-Jakob disease and kuru patients lack a mutation consistently found in the Gerstmann-Sträussler-Scheinker syndrome. Exp. Neurol., 108, 247-250, 1990.

204) Goldfarb, L. G., Brown, P., McCombie, W. R., Goldgaber, D., Swergold, G. D., Wills, P. R., Cervenakova, L., Baron, H., Gibbs, C. J. J., and Gajdusek, D. C. Transmissible familial Creutzfeldt-Jakob disease associated with five, seven, and eight extra octapeptide coding repeats in the PRNP gene, Proc. Natl. Acad. Sci. USA, 88, 10926-10930, 1991.

205) Palmer, M. S., Mahal, S. P., Campbell, T. A., Hill, A. F., Sidle, K. C. L., Laplanche, J.-L., and Collinge, J. Deletions in the prion protein gene are not associated with CJD. Hum. Molec. Genet., 2, 541-544, 1993.

206) Goldgaber, D., Goldfarb, L. G., Brown, P., Asher, D. M., Brown, W. T., Lin, S., Teener, J. W., Feinstone, S. M., Rubenstein, R., Kascsak, R. J., Boellaard, J. W., and Gajdusek, D. C. Mutations in familial Creutzfeldt-Jakob disease and Gerstmann-Sträussler-Scheinker's syndrome. Exp. Neurol., 106, 204-206, 1989.

207) Doh-ura, K., Tateishi, J., Sasaki, H., Kitamoto, T., and Sakaki, Y. Pro-> Leu change at position 102 of prion protein is the most common but not the sole mutation related to GerstmannSträussler syndrome. Biochem. Biophys. Res. Commun., 163, 974-979, 1989.

208) Goldfarb, L. G., Mitrova, E., Brown, P., Toh, B. H., and Gajdusek, D. C. Mutation in codon 200 of scrapie amyloid protein gene in two clusters of Creutzfeldt-Jakob disease in Slovakia. Lancet, 336, 514-515, 1990.

209) Goldfarb, L., Brown, P., Goldgaber, D., Garruto, R., Yanaghiara, R., Asher, D., and Gajdusek, D. C. Identical mutation in unrelated patients with Creutzfeldt-Jakob disease. Lancet, 336, 174-175, 1990.

210) Hsiao, K, K., Doh-ura, K., Kitamoto, T., Tateishi, J., and Prusiner, S. B. A prion protein amino acid substitution in ataxic GerstmannSträussler syndrome. Ann. Neurol., 26, 137, 1989.

211) Hsiao, K. K., Cass, C., Schellenberg, G. D., Bird, T., Devine-Gage, E., Wisniewski, H., and Prusiner, S. B. A prion protein variant in a family with the telencephalic form of Gerstmann-Sträussler-Scheinker syndrome. Neurology. 41, 631-684, 1991.

212) Tateishi, J., Kitamoto, T., Doh-ura, K., Sakaki, Y., Steinmetz, G., Tranchant, C., Warter. J. M., and Heldt, N. Immunochemical, molecular genetic, and transmission studies on a case of Gerstmann-Sträussler-Scheinker syndrome. Neurology, 40, 1578-1581, 1990.

213) Goldfarb, L., Korczyn, A., Brown, P., Chapman, J., and Gajdusek, D. C. Mutation in codon 200 of scrapie amyloid precursor gene linked to Creutzfeldt-Jakob disease in Sephardic Jews of Libyan and non-Libyan origin. Lancet, 336, 637638, 1990.

214) Gabizon, R., Meiner, Z., Cass, C., Kahana, E., Kahana, I., Avrahami, D., Abramsky, O., Scarlato, G., Prusiner, S. B., and Hsiao, K. K. Prion protein gene mutation in Libyan Jews with Creutzfeldt-Jakob disease. Neurology, 41, 160, 1991.

215) Hsiao, K., Meiner, Z., Kahana, E., Cass, C., Kahana, I., Avrahami, D., Scarlato, G., Abramsky, O., Prusiner, S. B., and Gabizon, R. Mutation of the prion protein in Libyan Jews with Creutzfeldt-Jakob disease. N. Engl. J. Med., 324, 1091-1097, 1991.

216) Goldfarb, L., G., Haltia, M., Brown, P., Nieto, A., Kovanen, J., McCombie, W. R., Trapp, S., and Gajdusek, D. C. New mutation in scrapie 
amyloid precursor gene (at codon 178) in Finnish Creutzfeldt-Jakob kindred. Lancet., 337, 425, 1991.

217) Ripoll, L., Laplanche, J.-L., Salzmann, M., Jouvet, A., Planques, B., Dussaucy, M., Chatelain, J., Beaudry, P., and Launay, J.-M. A new point mutation in the prion protein gene at codon 210 in Creutzfeldt-Jakob disease. Neurology, 43, 1934-1938, 1993.

218) Hsiao, K., Dlouhy, S., Farlow, M. R., Cass, C., Da Costa, M., Conneally, M., Hodes, M, E., Ghetti, B., and Prusiner, S. B. Mutant prion proteins in Gerstmann-Sträussler-Scheinker disease with neurofibrillary tangles. Nat. Genet., 1, 68-71, 1992.
219) Kitamoto, T. lizuka, R., and Tateishi, J. An amber mutation of prion protein in GerstmannSträussler syndrome with mutant PrP plaques. Biochem. Biophys. Res. Commun., 192, 525-531, 1993.

220) Kitamoto, T., Ohta, M., Doh-ura, K., Hitoshi, S., Terao, Y., and Tateishi, J. Novel missense variants of prion protein in Creutzfeldt-Jakob disease or Gerstmann-Sträussler syndrome. Biochem. Biophys. Res. Commun., 191, 709-714, 1993.

221) Prusiner, S. B. Transgenetics and cell biology of prion diseases: investigations of $\mathrm{PrP}^{\mathrm{sc}}$ synthesis and diversity. Brit. Med. Bul, 49, 873-912, 1993. 